\title{
Equity Market Liberalization in Emerging Markets
}

\author{
Geert Bekaert, Campbell R. Harvey, and Christian T. Lundblad
}

0 ne of the most important national policy decisions of the past 25 years has been the financial liberalization of equity markets across the world. Equity market liberalizations give foreign investors the opportunity to invest in domestic equity securities and domestic investors the right to transact in foreign equity securities.

It is important to distinguish between the concepts of liberalization and integration. For example, a country might pass a law that seemingly drops all barriers to foreign participation in local capital markets. This is a liberalization-but it might not be an effective liberalization that results in market integration. Indeed, there are two possibilities in this example. First, the market might have been integrated before the regulatory liberalization. That is, foreigners might have had the ability to access the market through other means, such as country funds and depository receipts. Second, the liberalization might have little or no effect because either foreign investors do not believe the regulatory reforms will be long lasting or other market imperfections exist.

Liberalizations must be dated to be studied, but pinpointing specific dates is difficult because countries have pursued varied liberalization strategies. Our paper begins by analyzing the progress that has been made on dating liberalizations. We examine regulatory changes, the ability of investors to access the local market via proxies such as country funds, and the behavior of foreign portfolio holdings.

If liberalization is effective, it leads to market integration, which has a fundamental impact on

\footnotetext{
Geert Bekaert is the L. Cooperman Professor of Finance and Economics at the Graduate School of Business, Columbia University, and a research associate at the National Bureau of Economic Research. Campbell R. Harvey is the J. Paul Sticht Professor of International Business at the Fuqua School of Business, Duke University, and a research associate at the National Bureau of Economic Research Christian T. Lundblad is an assistant professor of finance at the Kelley School of Business, Indiana University. The authors thank Xin Huang for excellent research support and Peter Henry and the participants of the Federal Reserve Bank of St. Louis's 27th Annual Economic Policy Conference, "Finance and Real Economic Activity," for helpful comments.

(c) 2003, The Southern and Southwestern Finance Association. This article is forthcoming in the Journal of Financial Research.
}

both the financial and real sectors of developing countries. Our paper also summarizes some recent research on the impact of liberalization on the real sector.

\section{FINANCIAL LIBERALIZATION \\ Official Equity Market Liberalization}

As a start, Bekaert and Harvey (2000) (BH) provide a detailed examination of the key economic events that could potentially impact the financial liberalization and reform process in a large number of emerging countries. ${ }^{1}$ Further, to explore the effects of foreign access to domestic equity markets, BH date an "official equity market liberalization" for each country - that is, a date of formal regulatory change giving foreign investors the opportunity to invest in domestic equity securities and domestic investors the right to transact in foreign equity securities. For example, Brazil rewrote its foreign investment law in May 1991. Resolution 1832 Annex IV stipulated that foreign institutions can own up to 49 percent of voting stock and 100 percent of nonvoting stock. Similarly, January 1992 signified a partial opening of the Korean stock market to foreigners, after which foreign investors could own up to 10 percent of domestically listed firms. In Table 1 , we present the $\mathrm{BH}$ official liberalization dates for 30 emerging equity markets. As can be observed, many liberalizations are clustered in the late 1980s or early 1990s. Based upon the chronologies presented in BH, Table 2 provides a more detailed analysis describing the particular regulatory changes that occurred at the BH official liberalization date. Generally, as in the examples provided above, these reforms involved (for the first time) the removal of restrictions on foreigners holding domestic equities. Further, these dates generally correspond to the liberalization dates provided by the International Finance Corporation (IFC); however, there are other "equity market liberalization" dates provided in this literature which, employing somewhat different

\footnotetext{
1 Detailed $\mathrm{BH}$ chronologies for each of the emerging market countries presented here are available in the country risk analysis at < http:// www.duke.edu/ charvey/Country_risk/couindex.htm >
} 


\section{Table 1}

\section{Equity Market Opening in Emerging Countries}

\begin{tabular}{|c|c|c|c|c|}
\hline Country & $\begin{array}{c}\text { Official } \\
\text { liberalization date }\end{array}$ & $\begin{array}{c}\text { First ADR } \\
\text { introduction }\end{array}$ & $\begin{array}{c}\text { First country } \\
\text { fund introduction }\end{array}$ & $\begin{array}{c}\text { Estimate of } \\
\text { increase in net } \\
\text { U.S. capital flows }\end{array}$ \\
\hline Argentina (ARG) & $11 / 89$ & $08 / 91$ & $10 / 91$ & $04 / 93$ \\
\hline Bangladesh (BGD) & $06 / 91$ & NA & NA & NA \\
\hline Brazil (BRA) & $05 / 91$ & $01 / 92$ & $10 / 87$ & $06 / 88$ \\
\hline Chile (CHL) & $01 / 92$ & $03 / 90$ & $09 / 89$ & $01 / 88$ \\
\hline Colombia (COL) & $02 / 91$ & $12 / 92$ & $05 / 92$ & $08 / 93$ \\
\hline Côte d'Ivoire (CIV) & 95 & $\mathrm{NA}$ & NA & NA \\
\hline Egypt (EGY) & 92 & $11 / 96^{*}$ & NA & NA \\
\hline Greece (GRC) & $12 / 87$ & 08/88 & $09 / 88$ & $12 / 86$ \\
\hline India (IND) & $11 / 92$ & $02 / 92$ & $06 / 86$ & $04 / 93$ \\
\hline Indonesia (IDN) & $09 / 89$ & $04 / 91$ & $01 / 89$ & $06 / 93$ \\
\hline Israel (ISR) & $11 / 93$ & $08 / 87^{*}$ & $10 / 92$ & NA \\
\hline Jamaica (JAM) & $09 / 91$ & 06/93* & NA & NA \\
\hline Jordan (JOR) & $12 / 95$ & $12 / 97^{*}$ & NA & NA \\
\hline Kenya (KEN) & $01 / 95$ & NA & NA & NA \\
\hline Korea (KOR) & $01 / 92$ & $11 / 90$ & $08 / 84$ & $03 / 93$ \\
\hline Malaysia (MYS) & $12 / 88$ & $08 / 92$ & $12 / 87$ & $04 / 92$ \\
\hline Mexico (MEX) & 05/89 & $01 / 89$ & $06 / 81$ & $05 / 90$ \\
\hline Morocco (MAR) & $06 / 88$ & 04/96* & $\mathrm{NA}$ & $\mathrm{NA}$ \\
\hline Nigeria (NGA) & $08 / 95$ & $05 / 98^{*}$ & NA & NA \\
\hline Pakistan (PAK) & $02 / 91$ & 09/94* & $07 / 91$ & $04 / 93$ \\
\hline Philippines (PHL) & $06 / 91$ & $03 / 91$ & $05 / 87$ & $01 / 90$ \\
\hline Portugal (PRT) & $07 / 86$ & $06 / 90$ & $08 / 87$ & $08 / 94$ \\
\hline South Africa (ZAF) & 96 & $06 / 94^{*}$ & $03 / 94$ & NA \\
\hline Sri Lanka (LKA) & $05 / 91$ & 03/94* & NA & NA \\
\hline Taiwan (TWN) & $01 / 91$ & $12 / 91$ & $05 / 86$ & $08 / 92$ \\
\hline Thailand (THA) & $09 / 87$ & $01 / 91$ & 07/85 & 07/88 \\
\hline Trinidad \& Tobago (TTO) & $04 / 97$ & NA & NA & NA \\
\hline Tunisia (TUN) & $06 / 95$ & 02/98* & NA & NA \\
\hline Turkey (TUR) & 08/89 & $07 / 90$ & $12 / 89$ & $12 / 89$ \\
\hline Venezuela (VEN) & $01 / 90$ & 08/91 & NA & $02 / 94$ \\
\hline Zimbabwe (ZWE) & $06 / 93$ & NA & NA & NA \\
\hline
\end{tabular}

NOTE: The official liberalization dates, date of first ADR issuance, and first country fund are based on Bekaert and Harvey (2000), augmented here to include ten additional emerging markets. The estimate of the break point in U.S. equity portfolio holdings is obtained from Bekaert and Harvey (2000), using the algorithm in Bai, Lumsdaine, and Stock (1998). The asterisks denote that we obtained "effective dates" from the Bank of New York (<http://www.adrbny.com>). The other "announcement" dates are from Miller (1999); however, he notes that the announcement usually preceeds the issue by only 40 days, on average. For South Africa, the first ADR introduction date is associated with the post-apartheid period; there were many ADRs in the early 1980s, which we ignore. NA represents not available. 
criteria, do differ significantly from those provided by BH for certain countries (see Henry, 2000a, Kim and Singal, 2000, and Levine and Zervos, 1998b).

To illustrate the difficulty associated with dating market integration, Table 3 presents chronologies of major economic events for two countries, Brazil and Korea. For example, over the 20-year period presented, Brazil (shown in panel A) introduced insider trading laws, undertook macroeconomic reforms, employed several different exchange rate regimes, and gradually allowed increased foreign direct and portfolio investment. Additionally, these events were not one-directional, as exchange rate and trade restrictions were reintroduced over the reform time-line. Taken together, this multifaceted reform effort makes the dating of economic and financial integration a matter of judgment, particularly as this and previous work are interested in isolating the financial and economic effects of an equity market liberalization (see Bekaert, Harvey, and Lundblad, 2001 and 2002). Further, Brazil is by no means unique or unusual; in panel $\mathrm{B}$, we display the comparable chronology for Korea, which exhibits the same challenging features. For example, Korea was admitted into the United Nations and initiated a political rapprochement with the Democratic People's Republic of Korea in 1991, the same year to which $\mathrm{BH}$ ascribe the equity market liberalization. This complete series of events makes the analysis somewhat challenging. Unfortunately, the simultaneity of macroeconomic, political, and financial reform is not the only factor potentially confounding an examination of a single reform's key economic effects. In practice, there are additional factors that may cloud the importance of the particular regulatory changes that BH (and others) document. First, it is possible that the investment restrictions were not binding prior to the reform. Second, the official regulatory changes permitting foreign investment are often implemented gradually. For instance, as can be observed in Table 3, the restrictions foreigners faced when investing in Korean securities were lifted only gradually throughout the 1990s. Hence, dating the "official liberalization" is not unambiguous. Third, although countries might undertake official regulatory reform efforts, foreign investors may still face significant liquidity costs; Chuhan (1994), for example, reports that market participants in many industrialized countries mentioned liquidity concerns as one of the major impediments to investing in emerging markets.

\section{Alternative Entry: Country Funds and American Depository Receipts}

Another challenge when dating an equity market liberalization is that many of these emerging markets were already indirectly open to foreign investment prior to official reform by way of country funds and American depository receipts (ADRs). A closed-end country fund is an investment company that invests in a portfolio of assets in a foreign country but issues a fixed number of shares domestically. Closed-end mutual funds were the original vehicles for foreign investment in emerging financial markets. For example, the Korea Fund partially opened up the Korean equity market to foreign investors in 1984, long before the capital market liberalizations of 1991. In contrast, ADRs are rights to foreign shares that trade in dollars on a U.S. exchange or over the counter. Further, since ADRs are treated as U.S. securities in most legal situations, they enable mutual funds, pension funds, and other U.S. institutions to hold securities that are fungible with foreign shares. Table 1 details the earliest country fund and ADR introduction for the emerging markets in our sample.

\section{The Intensity of Liberalization}

Market integration is usually a gradual process, and the speed of the process is determined by the particular situation in each individual country. When one starts from the segmented state, the barriers to investment are often numerous. Bekaert (1995) details three different categories of barriers to emerging market investment: (i) legal barriers; (ii) indirect barriers that arise because of information asymmetry, accounting standards, and investor protection; and (iii) risks that are especially important in emerging markets such as liquidity, political, economic policy, and currency risk. These barriers discourage foreign investment, and it is unlikely that any/all of these barriers disappear at a single point in time. Since reform is usually a gradual process, the usual 0/1 indicators variables are perhaps too coarse, failing to capture the intensity or comprehensiveness of the liberalization.

Empirical models have been developed that allow the degree of market integration to change through time (see Bekaert and Harvey, 1995). This moves us away from the static segmented/integrated paradigm to a dynamic partial segmentation/partial integration setting. Whereas these models are indirect, relying on a model and econometric estimation to infer changes in the degree of integration, there are more direct measures available. Bekaert (1995) 


\section{Table 2}

\section{Classifying an Official Equity Market Liberalization}

\begin{tabular}{lc} 
Country & $\begin{array}{c}\text { Official } \\
\text { liberalization date }\end{array}$ \\
\hline Argentina (ARG) & $11 / 89$ \\
Bangladesh (BGD) & $06 / 91$
\end{tabular}

Brazil (BRA)

05/91

Chile (CHL)

01/92

Colombia (COL)

Côte d'Ivoire (CIV)

$02 / 91$

95

Egypt (EGY)

92

Greece (GRC)

India (IND)

$11 / 92$

Indonesia (IDN)

$09 / 89$

Israel (ISR)

Jamaica (JAM)

09/91

Jordan (JOR)

12/95

Kenya (KEN)

$01 / 95$

Korea (KOR)
Free repatriation of capital, remittance of dividends, and capital gains.

Purchases of Bangladesh shares and securities by nonresidents, including nonresident Bangladeshis, in stock exchange in Bangladesh allowed, subject to meeting procedural requirements.

Foreign investment law changed. Resolution 1832 Annex IV stipulates that foreign institutions can now own up to $49 \%$ of voting stock and $100 \%$ of nonvoting stock. Economic ministers approve rules allowing direct foreign investments; $15 \%$ tax on distributed earnings and dividends but no tax on capital gains. Foreign investment capital must remain in country for 6 years (was 12 years). Bank debt restructuring agreement.

Liberalization of foreign investment, reducing the minimum holding period and tax on investment income.

Foreigners have the same rights as domestic investors.

National Assembly approves a new Ivoirian Investment Code. For all practical purposes, there are no significant limits on foreign investment-or differences in the treatment of foreign and national investors-either in terms of levels of foreign ownership or sector of investment.

Capital Market Law 95 grants foreign investors full access to capital markets. There are no restrictions on foreign investment in the stock exchange.

Liberalization of currency controls allows foreigners to participate in the equity market and to repatriate their capital gains.

Government announces that foreign portfolio investors will be able to invest directly in listed Indian securities

Minister of Finance allows foreigners to purchase up to $49 \%$ of all companies listing shares on the domestic exchange, excluding financial firms.

Nonresidents allowed to deposit into nonresident accounts all incomes received from Israeli securities and real estate, even if these were purchased from sources other than nonresident accounts.

All inward and outward capital transfers permitted, except that financial institutions must match their Jamaican dollar liabilities to their clients with Jamaican dollar assets.

Foreign investment bylaws passed, allowing foreign investors to purchase shares without government approval.

Restrictions on investment by foreigners in shares and government securities removed. The Capital Market Authority Act amended to allow foreign equity participation of up to $40 \%$ of listed companies, while individuals are allowed to own up to $5 \%$ of listed companies.

Partial opening of the stock market to foreigners. Foreigners can now own up to $10 \%$ of domestically listed firms; 565 foreign investors registered with the Securities Supervisory Board. 


\section{Table 2 cont'd}

\section{Classifying an Official Equity Market Liberalization}

\begin{tabular}{|c|c|c|}
\hline Country & $\begin{array}{l}\text { Official } \\
\text { lization date }\end{array}$ & \\
\hline Malaysia (MYS) & $12 / 88$ & $\begin{array}{l}\text { Budget calls for liberalization of foreign ownership policies to attract } \\
\text { more foreign investors. }\end{array}$ \\
\hline Mexico (MEX) & $05 / 89$ & $\begin{array}{l}\text { Restrictions on foreign capital participation in new direct foreign } \\
\text { investments liberalized substantially. }\end{array}$ \\
\hline Morocco (MAR) & $06 / 88$ & $\begin{array}{l}\text { Foreigners permitted to subscribe to two Treasury bond issues of } \\
\text { June 1988; repatriation of capital and income from the investment } \\
\text { granted. }\end{array}$ \\
\hline Nigeria (NGA) & $08 / 95$ & Nigerian market open to foreign portfolio investment. \\
\hline Pakistan (PAK) & $02 / 91$ & $\begin{array}{l}\text { Restrictions removed on foreigners or nonresident Pakistanis purchasing } \\
\text { shares of a listed company or subscribing to public offerings of } \\
\text { shares, subject to some approvals. }\end{array}$ \\
\hline Philippines (PHL) & $06 / 91$ & $\begin{array}{l}\text { Foreign Investment Act signed into law. The Act removes, over a period } \\
\text { of three years, all restrictions on foreign investments. }\end{array}$ \\
\hline Portugal (PRT) & 07/86 & $\begin{array}{l}\text { All restrictions on foreign investment removed except for arms-sector } \\
\text { investments. }\end{array}$ \\
\hline South Africa (ZAF) & 96 & $\begin{array}{l}\text { Restrictions on foreign membership in the Johannesburgh Stock } \\
\text { Exchange lifted. }\end{array}$ \\
\hline Sri Lanka (LKA) & $1 / 90$ & $\begin{array}{l}\text { Companies incorporated abroad permitted to invest in securities } \\
\text { traded at the Colombo Stock Exchange, subject to the same terms } \\
\text { and conditions as those applicable to such investments by approved } \\
\text { national funds, approved regional funds, and nonresident individuals. }\end{array}$ \\
\hline Taiwan (TWN) & $01 / 91$ & $\begin{array}{l}\text { Implementation date of phase two of liberalization plan. Eligible foreign } \\
\text { institutional investors may now invest directly in Taiwan securities, } \\
\text { subject to approval. }\end{array}$ \\
\hline Thailand (THA) & $09 / 87$ & $\begin{array}{l}\text { Inauguration of the Alien Board on Thailand's Stock Exchange. The } \\
\text { Alien Board allows foreigners to trade stocks of those companies } \\
\text { that have reached their foreign investment limits. }\end{array}$ \\
\hline Trinidad \& Tobago (TTO) & $04 / 97$ & $\begin{array}{l}\text { Companies Act in force. Under the Companies Ordinance and the } \\
\text { Foreign Investment Act, a foreign investor may purchase shares in a } \\
\text { local corporation. However, foreign investors must obtain a license } \\
\text { before they can legally acquire more than } 30 \% \text { of a publicly held } \\
\text { company. }\end{array}$ \\
\hline Tunisia (TUN) & $06 / 95$ & Inward portfolio investment partially liberalized. \\
\hline Turkey (TUR) & $08 / 89$ & $\begin{array}{l}\text { Foreign investors permitted to trade in listed securities with no } \\
\text { restrictions at all and pay no withholding or capital gains tax provided } \\
\text { they are registered with the Capital Markets Board and the Treasury. }\end{array}$ \\
\hline Venezuela (VEN) & $01 / 90$ & $\begin{array}{l}\text { Decree } 727 \text { opens foreign direct investment for all stocks except bank } \\
\text { stocks. }\end{array}$ \\
\hline Zimbabwe (ZWE) & $06 / 93$ & $\begin{array}{l}\text { Zimbabwe Stock Exchange opened to foreign portfolio investment, } \\
\text { subject to certain conditions. }\end{array}$ \\
\hline
\end{tabular}




\title{
Table 3
}

\section{Most Important Events}

\author{
Panel A: Brazil \\ Date \\ 76 Introduction of insider trading laws. \\ 78 First prosecution under insider trading laws. \\ 02/86 Cruzado plan (price and wage controls). \\ 09/86 Fixed nominal exchange rate abandoned. \\ 01/87 Major provisions of Cruzado plan abandoned. \\ 03/87 CVM Resolution 1289 Annex II limits foreign direct investment through special conditions. \\ 89 Deposit rates fully liberalized. Mehrez and Kaufmann liberalization date. \\ 03/90 Collor Plan introduces a new currency and taxes stock-market transactions heavily. \\ 91 Elimination of exclusive broker system. Creation of NYSE-like system. \\ 05/91 Foreign investment law changed. Resolution 1832 Annex IV stipulates that foreign institutions can now \\ own up to $49 \%$ of voting stock and $100 \%$ of non-voting stock. Economic ministers approve rules allowing \\ direct foreign investments; $15 \%$ tax on distributed earnings and dividends but no tax on capital gains. \\ Foreign investment capital must remain in country for 6 years (was 12 years). Bank debt restructuring \\ agreement. \\ 05/91 Bekaert/Harvey official liberalization date. \\ 06/30/92 Foreign investors authorized to operate in the options and futures markets related to securities, exchange, \\ and interest rates. \\ 94 Banking crises (1994-95). \\ 10/94 New 15\% tax on all consumer loans and installment payments by banks and businesses. \\ 03/06/95 New exchange-rate system based on bands introduced. Band set at R \$0.86 to R \$0.90 per U.S. dollar until \\ May 2, when it changed to R\$0.86 to R $\$ 0.98$ per U.S. dollar. \\ 05/95 Trade policy turns inward as import quotas introduced and tariffs increased. \\ 10/97 Brazil stock market suffers from the domino effect caused by Hong Kong market crash; \$5 billion of \\ reserves used to defend the currency. \\ 11/97 Brazil's legislature approves austerity package.
}

and Edison and Warnock (2001) propose a continuous measure of equity market "openness" designed to reflect the foreign "investability" of these markets. The measure is based on the ratio of the market capitalization of the constituent firms comprising the IFC investable index to those that comprise the IFC global index for each country. The IFC global index, subject to some exclusion restrictions, ${ }^{2}$ is designed to represent the overall market portfolio for each country, whereas the IFC investable index is designed to better represent a portfolio of domestic equities that are available to foreign investors. Hence, a ratio of 1 means that all of the stocks are available to foreign investors.

2 For a more complete description of the methodology behind the construction of the SP/IFC indices, see Standard \& Poor's (2000).
We present the "investability" measure in Figure 1 for two of the markets we consider, Brazil and Korea. As can be seen, for these countries, this measure increases over time, potentially reflecting the intensity of the liberalization. Indeed, the investability measure for Korea begins at 0 in 1989 and increases to just below 1 by 2001. For comparison, we also note for each country the BH official liberalization date. In each case, the (first) major regulatory reform is indeed associated with a significant increase in the investability measure; however, the move certainly does not suggest full foreign access subsequent to the official date. Rather, the official liberalization date is generally associated with the first big jump in this measure, but large moves in the investability index may follow. For instance, foreign access to the Korean equity market increased 


\section{Table 3 cont'd}

\section{Most Important Events}

Panel B: Korea

Date

04/87 Trade liberalization measures announced.

07/01/87 Certain tax privileges granted to attract FDI reduced, and after-investment controls relaxed to put foreigninvested companies and local companies on the same basis.

12/28/87 Overseas investments by Korean residents of less than US\$1 million automatically approved, and the upper limit on investment free from government screening increased from US\$3 million to US\$5 million, regardless of purposes of investment.

89 Foreign exchange controls phased out.

11/90 First ADR announced.

01/03/91 Market opening to foreign investors. Notification system makes authorization of foreign investment subject to approval or notification. Foreign participation easier under new law. Repatriation of capital freely permitted.

09/91 Korea admitted into the United Nations. Announcement that stock market will open to investors in January 1992.

01/92 Partial opening of the stock market to foreigners. Foreigners can now own up to 10\% of domestically listed firms; 565 foreign investors registered with the Securities Supervisory Board.

01/92 Bekaert/Harvey official liberalization date.

12/94 Limit of foreign ownership of domestically listed firms raised from $10 \%$ to $12 \%$. Government announces intention to raise the overall limit from $12 \%$ to $15 \%$ in 1995.

05/95 International financial institutions permitted to issue won-denominated bonds in the domestic financial market.

07/95 Government raises foreign stock ownership limit from $12 \%$ to $15 \%$ and the limit for single investors from $3 \%$ to $5 \%$. Registration period for foreign investment decreased from 14 to 5 days.

09/95 Government announces foreign firms will be able to list on the Korean Stock Exchange as of 1996.

04/01/96 Ceilings on securities investments by residents abolished.

05/96 Limit of foreign ownership of domestically listed firms raised from $15 \%$ to $18 \%$.

09/96 Government relaxes foreign ownership restrictions from $18 \%$ to $20 \%$ and from $12 \%$ to $15 \%$ for state-owned enterprises.

05/97 Government raises foreign ownership restriction from $20 \%$ to $23 \%$.

$11 / 97$ Government raises the foreign share-holding limit from $23 \%$ to $26 \%$; state-run firms' limits raised to $21 \%$ from $18 \%$.

12/97 Government announces new 50\% foreign investment ceiling.

05/98 Foreign investment limit on Korean securities raised to 55\%. Foreign investment limit on state-run corporations boosted from $25 \%$ to $30 \%$.

05/25/98 Controls on capital and money market instruments: Foreigners free to purchase domestic collective investment securities without restriction. Controls on direct investment: Foreign investors allowed to take over corporations, except defense-related companies, and the ceiling on the amount of stock foreigners may acquire in all companies without the approval of the board of directors is abolished. 


\section{Equity Market Liberalization Intensity}

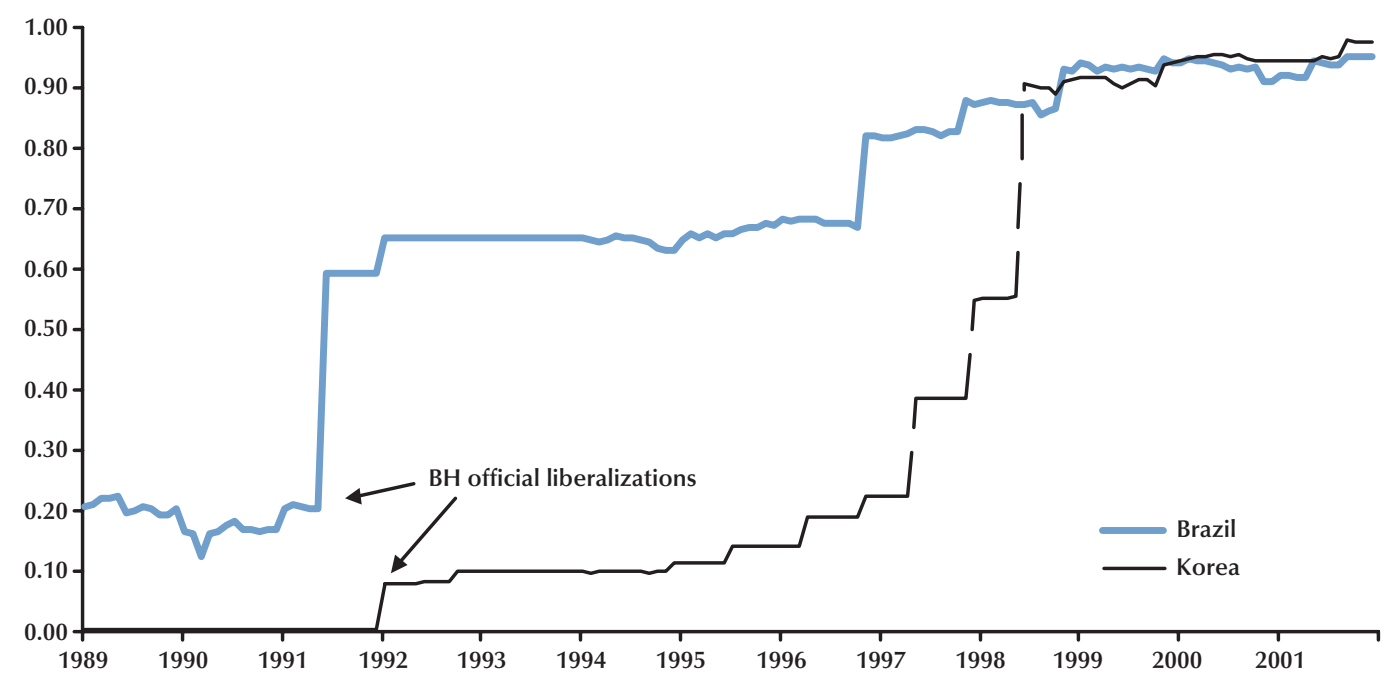

SOURCE: Edison and Warnock (2001).

significantly in 1997 and 1998 (see Table 3) and is associated with large jumps in the investability index. The corresponding intensity measures for other countries are very similar (see Edison and Warnock, 2001, for a more detailed analysis of this measure across a large collection of emerging markets).

\section{Foreign Equity Portfolio Holdings}

A second alternative designed to measure the intensity or quality of reforms is to directly investigate changes in the level of foreign equity portfolio holdings in these countries. It makes sense that as barriers to entry decrease in emerging equity markets, foreign capital flows in. One would like to document the observable points at which foreign investors are significantly changing their portfolio holdings in these markets, but, unfortunately, the data are somewhat limited along this dimension. The only high-frequency data available are U.S. net capital flows to emerging markets, published monthly in the U.S. Treasury Bulletin. If one is willing to take the U.S. transactions as a proxy for more general foreign equity market activity in these countries, then an estimate of U.S. ownership can be obtained by cumulating the net equity flow data (adjusting for local equity market appreciation). The United States' presence in these markets is likely to be highly correlated with the aggregate foreign presence.
Nevertheless, U.S. holdings estimates based upon the net portfolio flow data are not without problems. First, foreign investors may not hold the precise equity portfolio employed to account for the value appreciation in the cumulation of the net flows. Second, the U.S. data on cross-border purchases and sales of securities indicate where U.S. investors are purchasing foreign securities, but not the bona fide residence of the issuer of the foreign security. Hence, large observed net flows to financial centers may actually reflect emerging equity market investment through these intermediaries that one is unable to track, and so estimates of U.S. portfolio holdings may be consequently understated. The Bureau of Economic Analysis (BEA) conducted benchmark surveys of actual U.S. holdings of foreign securities in March 1994 and December 1997 and 2000. Warnock and Cleaver (2002) show that estimated U.S. equity portfolio holdings based upon the cumulated U.S. net equity flows starting in 1994 differ significantly in many cases from the benchmark survey amounts as of 1997 . They find that U.S. holdings of foreign securities are indeed substantially underestimated, suggesting many U.S. transactions in foreign securities are going through intermediaries in other countries, particularly the United Kingdom. 


\section{Figure 2}

\section{Estimated U.S. Equity Portfolio Holdings (US\$ Billions)}

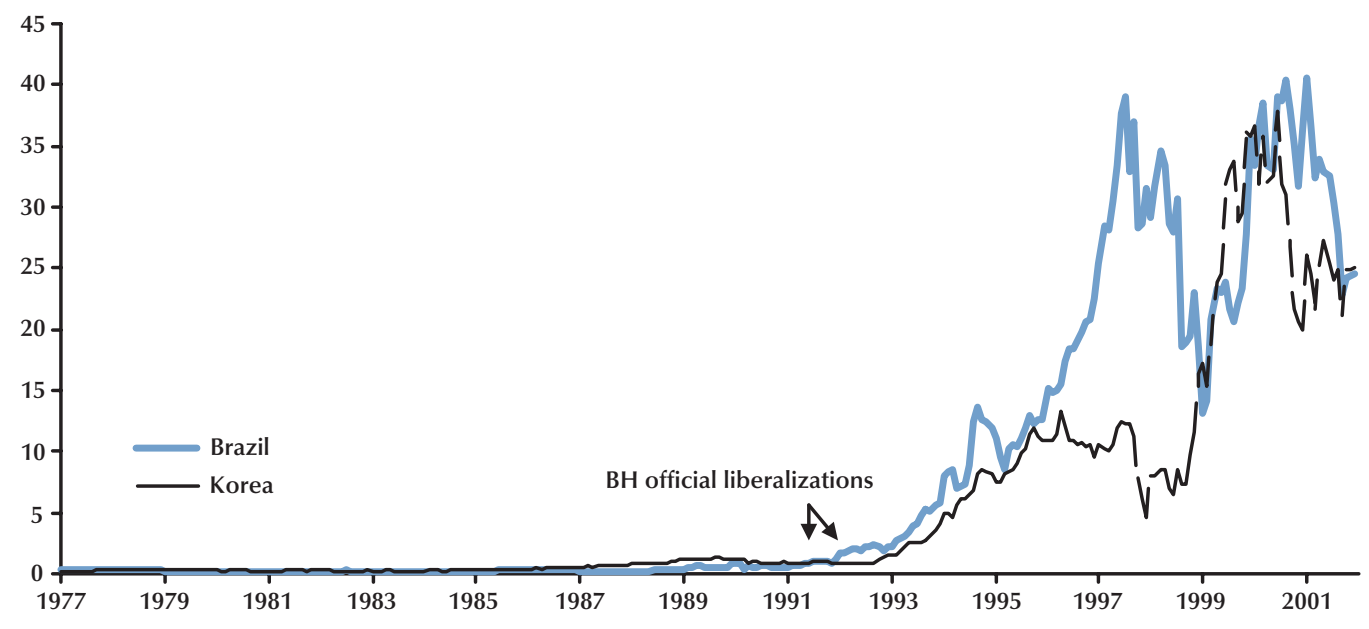

SOURCE: Thomas and Warnock (2002).

To deal with this shortcoming, Thomas and Warnock (2002) provide modified estimates of U.S. equity portfolio holdings that employ the monthly net equity flow data, but are also anchored at the BEA survey of U.S. holdings amounts in 1994 and 1997. This methodology exploits the high-frequency feature of the U.S. net flow data, but corrects for the documented underestimation by also employing the infrequent but high-quality, survey-based U.S. holdings data. Similar to BH and Bekaert, Harvey, and Lumsdaine (2002a,b), they form baseline holdings estimates, denoted $O w n_{i, t}$, at the end of a month by adjusting the previous month's holdings for estimated price and exchange rate changes and then add the current month's net purchases:

$$
O w n_{i, t}=O w n_{i, t-1} *\left(1+R_{i, t}\right)+\text { Flow }_{i, t},
$$

where $O w n_{i, t}$ is the estimated U.S. holdings of country $i$ 's securities at the end of month $t$; Flow ${ }_{i, t}$ is the net U.S. purchases of country $i$ 's securities during month $t$; and $R_{i, t}$ is an appropriate equity return (with dividends) required to revalue last period's holdings. They also correct for transaction costs and stock swaps. Recall that these unadjusted U.S. holdings amounts will be understated. According to the December 1997 data, for example, this methodology resulted in a holdings estimate $O w n_{i, 12 / 1997}$ that differed significantly from the benchmark survey. Thomas and Warnock (2002) also employ a grid search methodology to adjust the net equity flows in each inter-survey month by an amount that will equate $O w n_{i, 12 / 1997}$ to its benchmark survey level. ${ }^{3}$ For many countries, the estimates extend back to 1977 , but some begin later as the equity price data necessary for the valuation adjustment are not uniformly available. In Figure 2, we display the estimated U.S. holdings of Brazilian and Korean equities, along with the associated BH official equity market liberalization dates. As can be seen, the estimated holdings are effectively zero in dollar terms prior to the official liberalization; but they subsequently explode, reaching $\$ 24.3$ and $\$ 24.8$ billion (U.S.), respectively, by the end of 2001.

\section{Estimated Breaks in U.S. Equity Portfolio}

Holdings. BH and Bekaert, Harvey, and Lumsdaine (2002a) employ similar estimates of U.S. equity portfolio holdings to test for a structural break in the ownership series to econometrically identify the point at which the foreign presence in these markets increases significantly. The idea is that a structural shift in the foreign presence in the markets may be a better indicator of the quality of equity market liberalization; however, it should be noted that foreign capital will also be attracted by strong growth opportunities in addition to consid-

\footnotetext{
3 For 16 of the emerging markets considered in this paper, Thomas and Warnock were kind enough to share their adjusted estimates of U.S. equity holdings.
} 
erations such as the comprehensiveness, quality, and stability of capital market reforms. Note, the holdings data reflect both increased U.S. net transactions as well as the significant (and well documented) equity appreciation observed for these markets over the post-liberalization period (see BH and Henry, 2000a). Consequently, to control for the valuation component, they divide these figures by the domestic equity market capitalization. BH and Bekaert, Harvey, and Lumsdaine (2002a) employ the endogenous break point tests detailed in Bai, Lumsdaine, and Stock (1998), which search for a break in the mean within the context of an autoregressive model for the U.S. ownership series. Additionally, the procedure yields a break date with a 90 percent confidence interval. We report the $\mathrm{BH}$ estimated portfolio holdings break dates in the last column of Table 1 . As can be seen, there are several countries for which the official liberalization date and estimated break date are within a year or two of one another; see, for example, Turkey which has an official liberalization in August 1989 and an estimate of the portfolio holding break date in December of that same year. In contrast, there are several countries for which the dates are quite different (see, for example, Argentina, Portugal, and Venezuela). Taken together, the lack of uniformity across these dates presents a challenge to researchers in this area. For this reason, it is important to evaluate the robustness of any estimated liberalization effects to alternative dating schemes.

In Figure 3 (panels A through P), we present the ratio of the estimated U.S. equity portfolio holdings (from Thomas and Warnock, 2002) to the market capitalization of the Morgan Stanley Capital International (MSCI) (2001) indices for each country (which they use to make valuation adjustments). Below each estimate, we provide the $\mathrm{BH}$ official liberalization date, the date associated with either the first country fund or ADR, and the estimated break date. Additionally, we highlight key macroeconomic, trade, legal, and financial reforms that may impact foreign interest and/or access. As can be seen, across almost all of the countries considered, estimated U.S. holdings of domestic equities in these countries comprised almost none of the domestic market capitalization at the start dates; in contrast, by the end of 2001, the U.S. equity holdings exceeded 25 percent, on average, of the MSCI index capitalization across these markets, with several countries exceeding 50 percent. It is important to realize that these holdings do not reflect the percent of total market capitalization held by U.S. residents because the MSCI indices represent only between 50 percent and 70 percent of the total market capitalization. Hence, a 25 percent holding translates approximately into a $(0.25$ times $0.6=) 15$ percent U.S. holding. These figures, showing a strong upward trend in almost every case, demonstrate a dramatic change in the importance of foreign investors to the domestic equity markets in each of these countries over the past two decades. The more important question, however, is whether this increased foreign presence has significantly altered or improved (i) the level of financial development and (ii) real economic development through growth. These questions are the subject of our recent work (see Bekaert, Harvey, and Lundblad, 2001 and 2002).

\section{ECONOMIC EFFECTS OF FINANCIAL LIBERALIZATION}

There are a number of channels through which financial liberalization may affect the real economy. First, once they are allowed access, foreign investors, exploiting the benefits of diversification, will drive up domestic equity market values; $\mathrm{BH}$ and Henry (2000a) demonstrate that the cost of capital falls subsequent to major regulatory reforms that permit foreign investors access to domestic equity markets. Second, Henry (2000b) and Bekaert, Harvey, and Lundblad (2002) document that aggregate domestic investment increases significantly after liberalization, potentially stimulating economic growth. There is also a booming literature (see, for example, Atje and Jovanovic, 1993, King and Levine, 1993, and Levine and Zervos, 1998a) that associates enhanced economic growth with deeper financial markets and banking sectors. Because equity market liberalization promotes financial development and liquidity (see Bekaert, Harvey, and Lundblad, 2002), this may provide an additional channel through which liberalization stimulates growth. Finally, as foreign investors may demand improved corporate governance and transparency in these countries, liberalization may reduce the wedge between costs of external and internal financing at the firm level, stimulating corporate investment (see Love, 2000). In this paper, we summarize some recent evidence on the liberalization effects on real gross domestic product (GDP) and investment growth for a collection of developing economies that house emerging equity markets.

For a collection of emerging and frontier markets 


\section{Figure 3A}

\section{U.S. Share of MSCI Market Capitalization in Argentina}

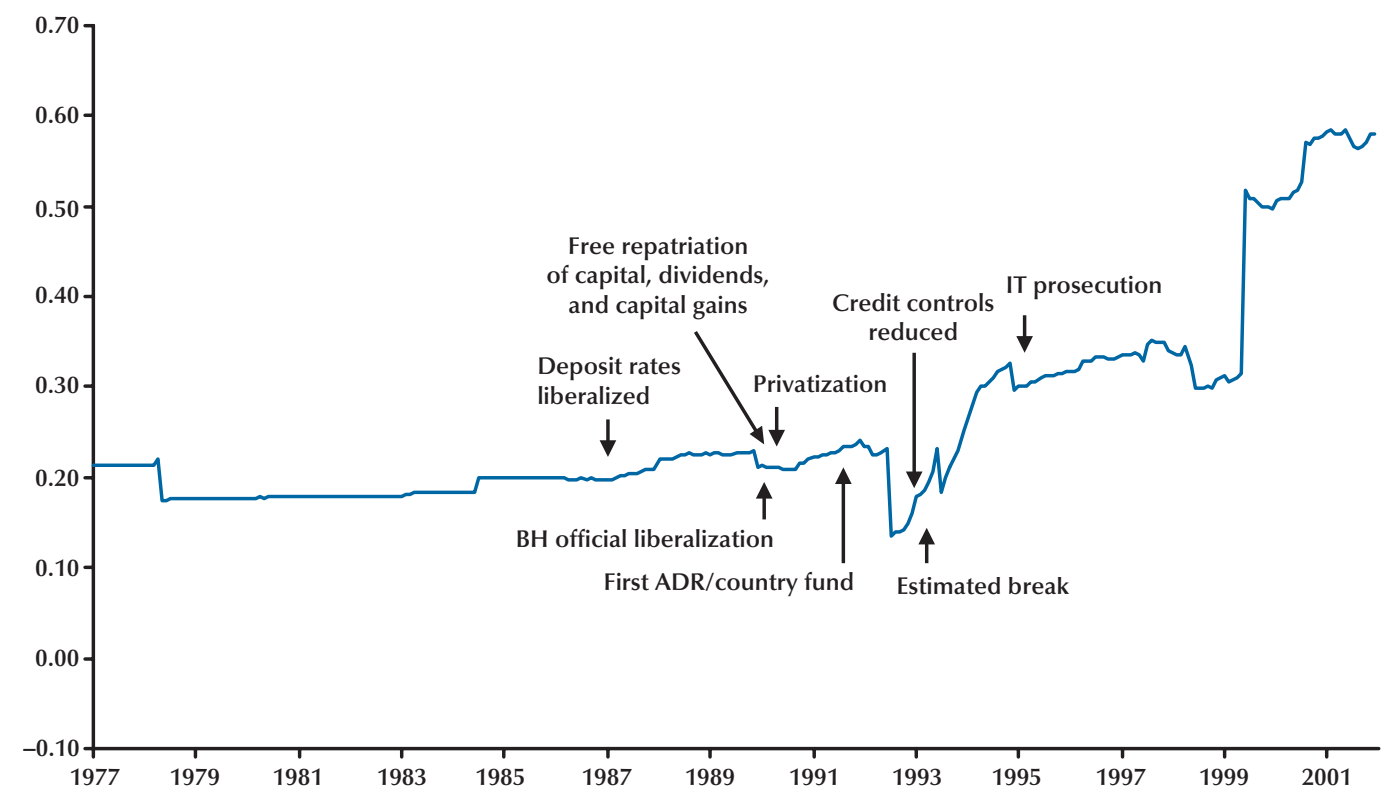

\section{Figure 3B}

U.S. Share of MSCI Market Capitalization in Brazil

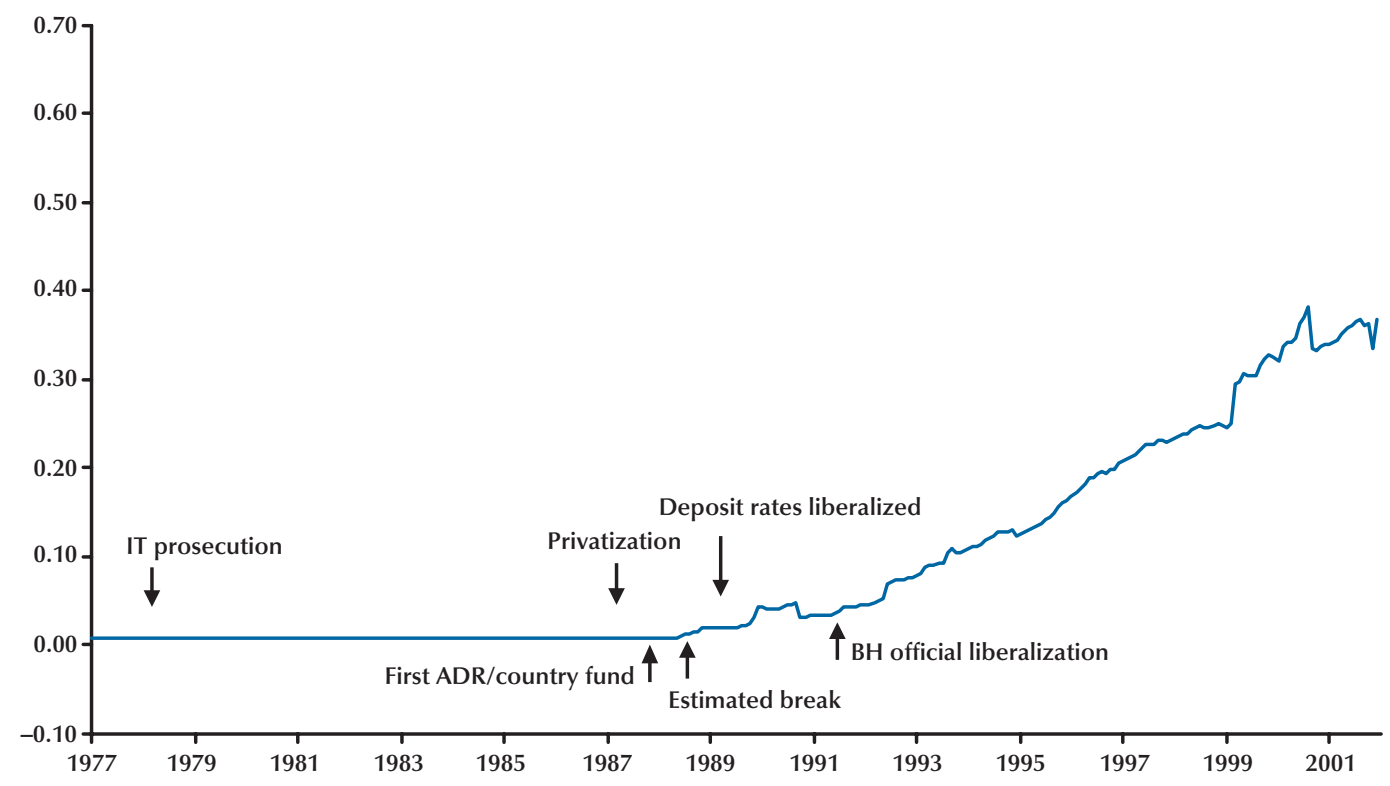




\section{U.S. Share of MSCI Market Capitalization in Chile}

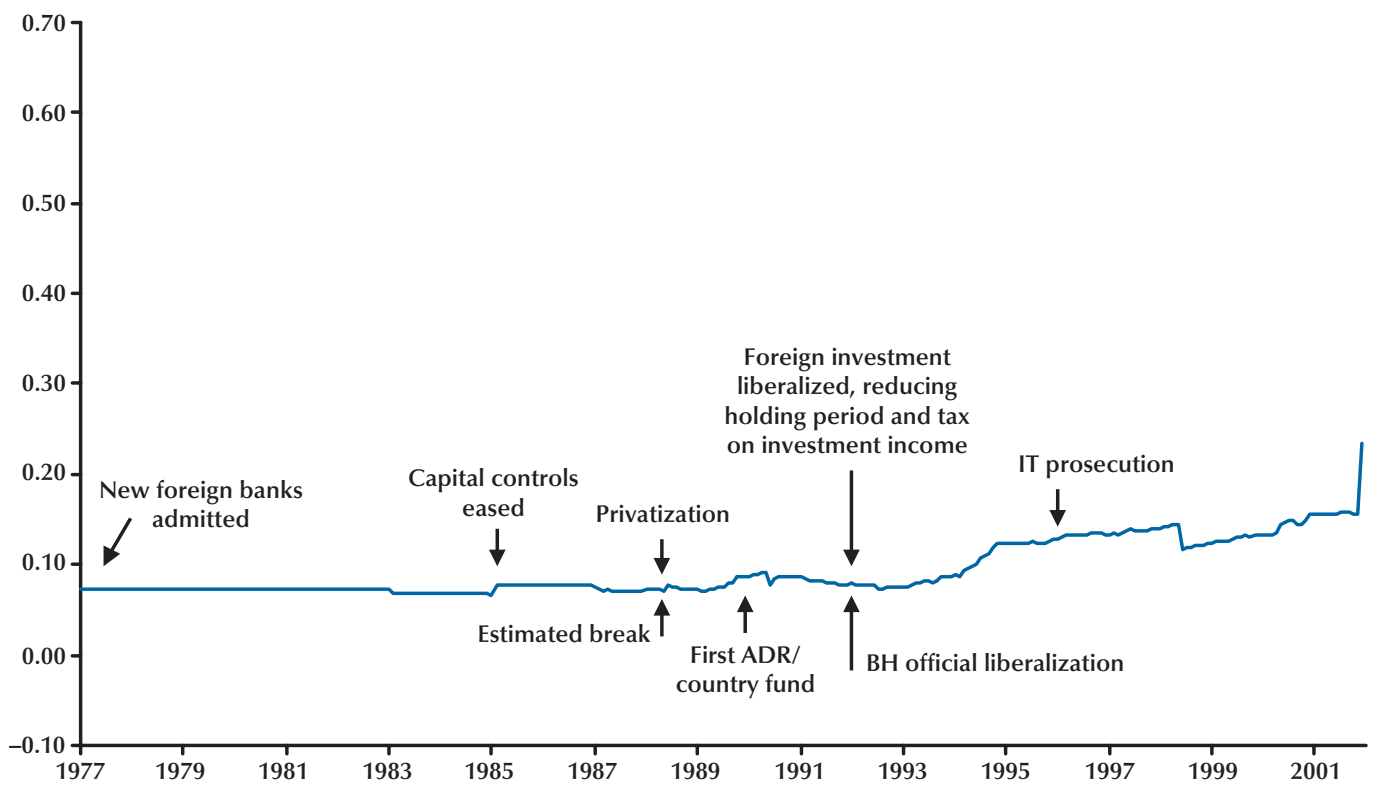

\section{U.S. Share of MSCI Market Capitalization in Colombia}

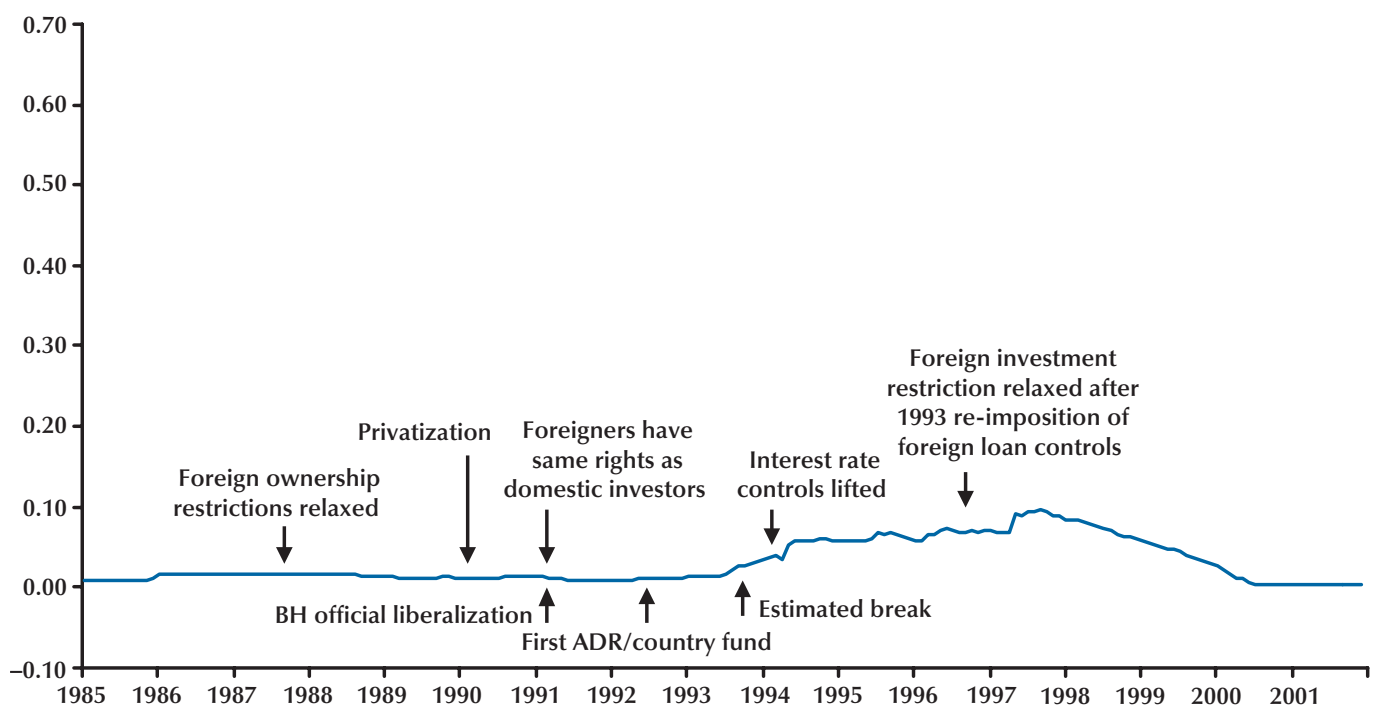




\section{Figure 3E}

\section{U.S. Share of MSCI Market Capitalization in Greece}

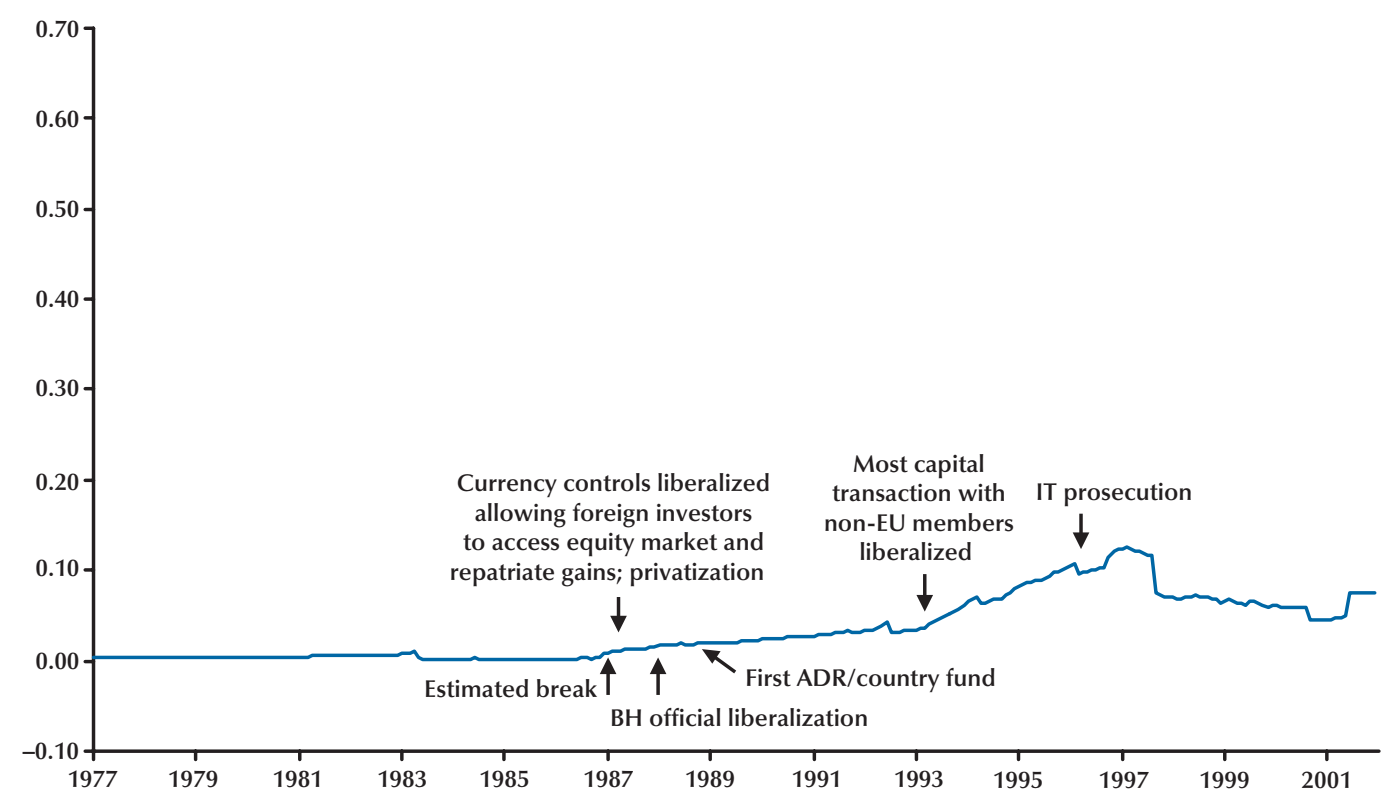

\section{Figure 3F}

\section{U.S. Share of MSCI Market Capitalization in India}

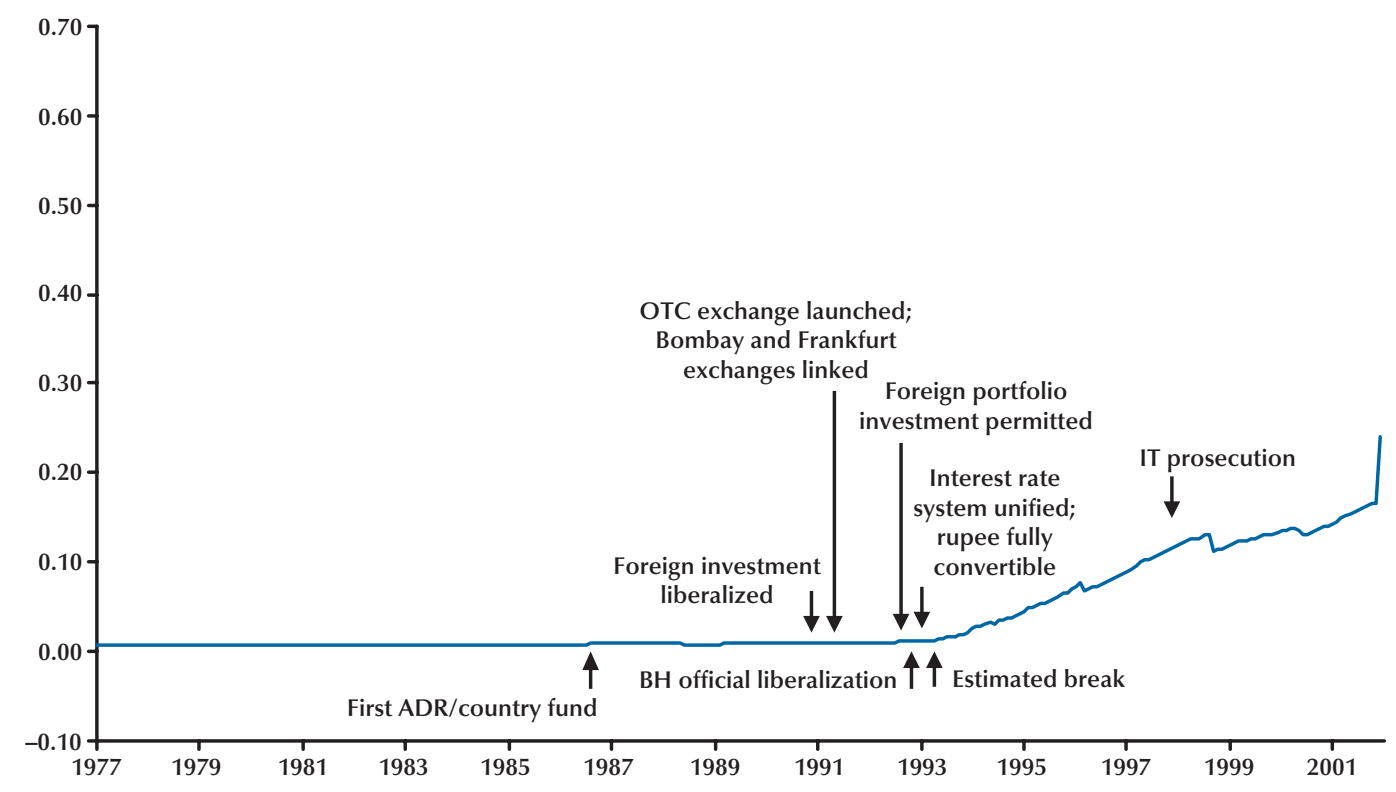




\section{U.S. Share of MSCI Market Capitalization in Indonesia}

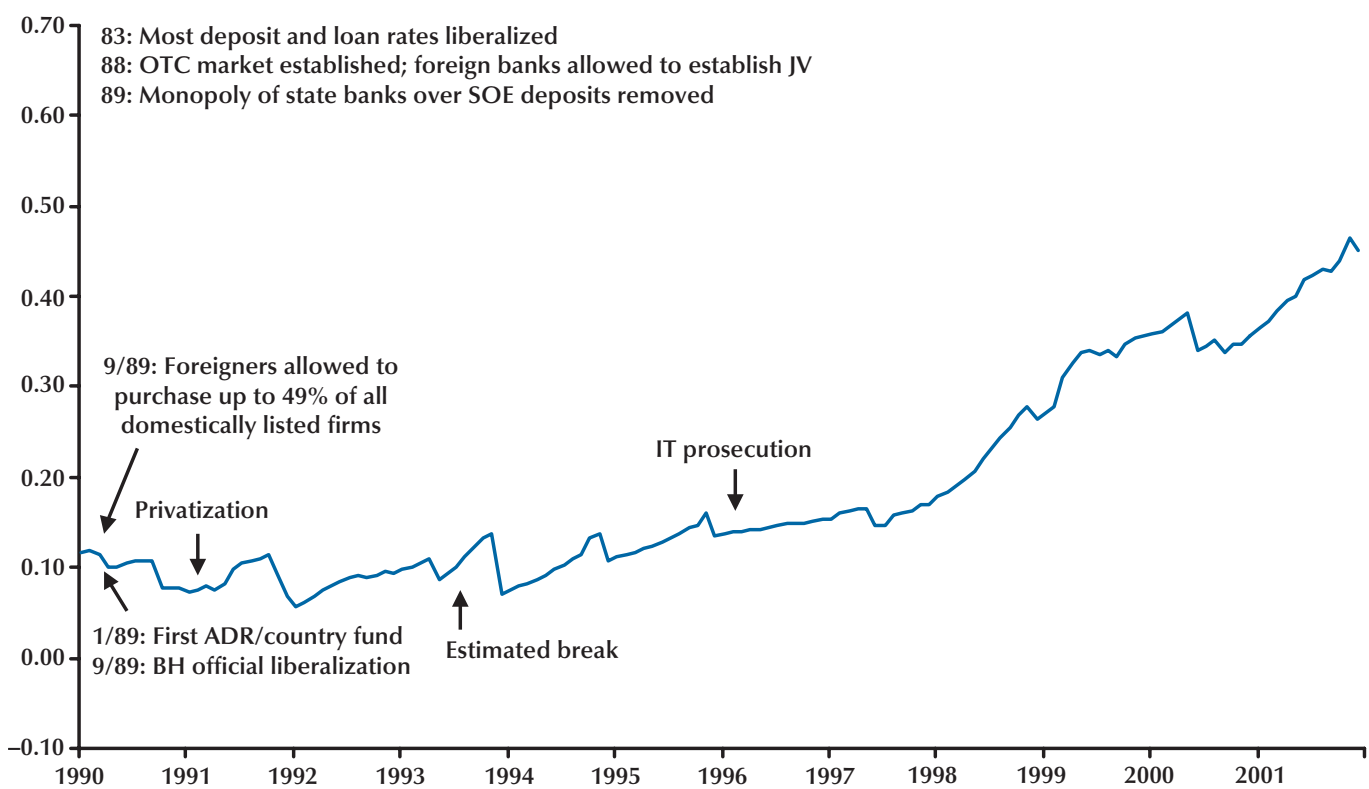

\section{U.S. Share of MSCI Market Capitalization in Korea}

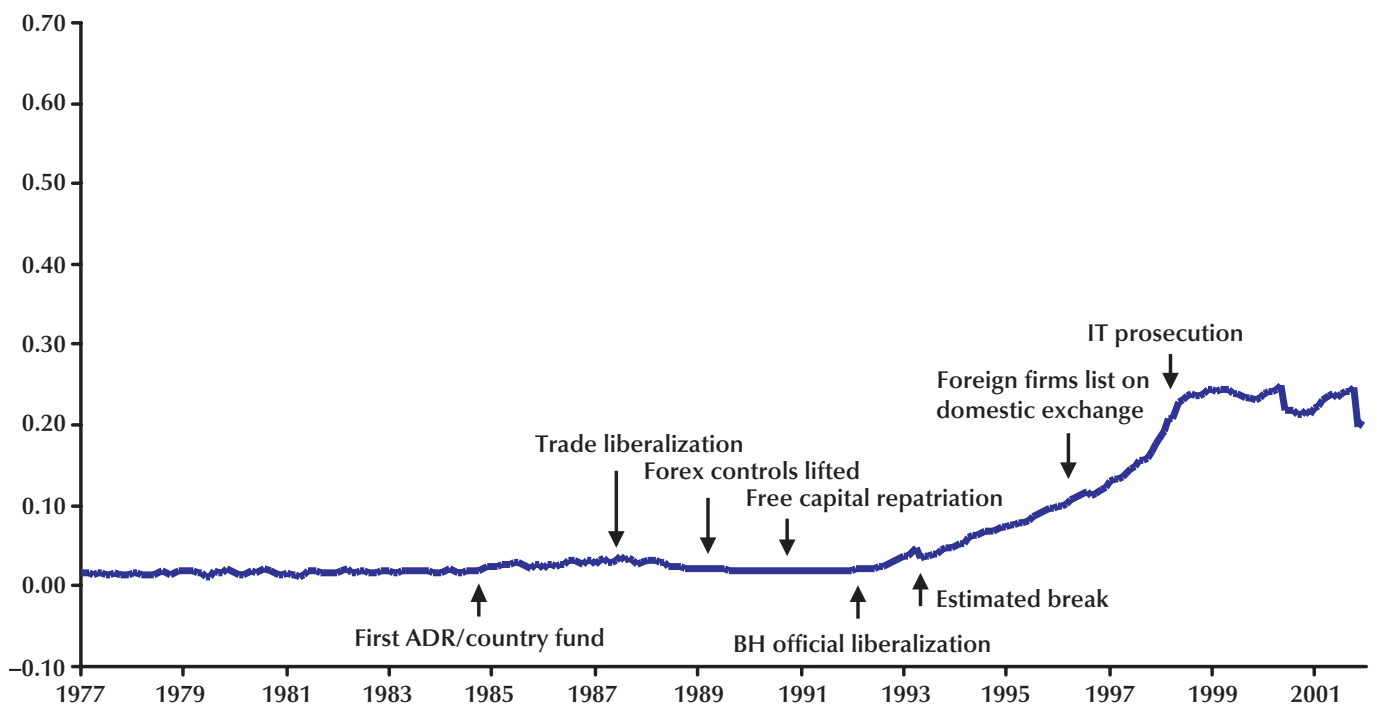




\section{Figure 3I}

\section{U.S. Share of MSCI Market Capitalization in Malaysia}

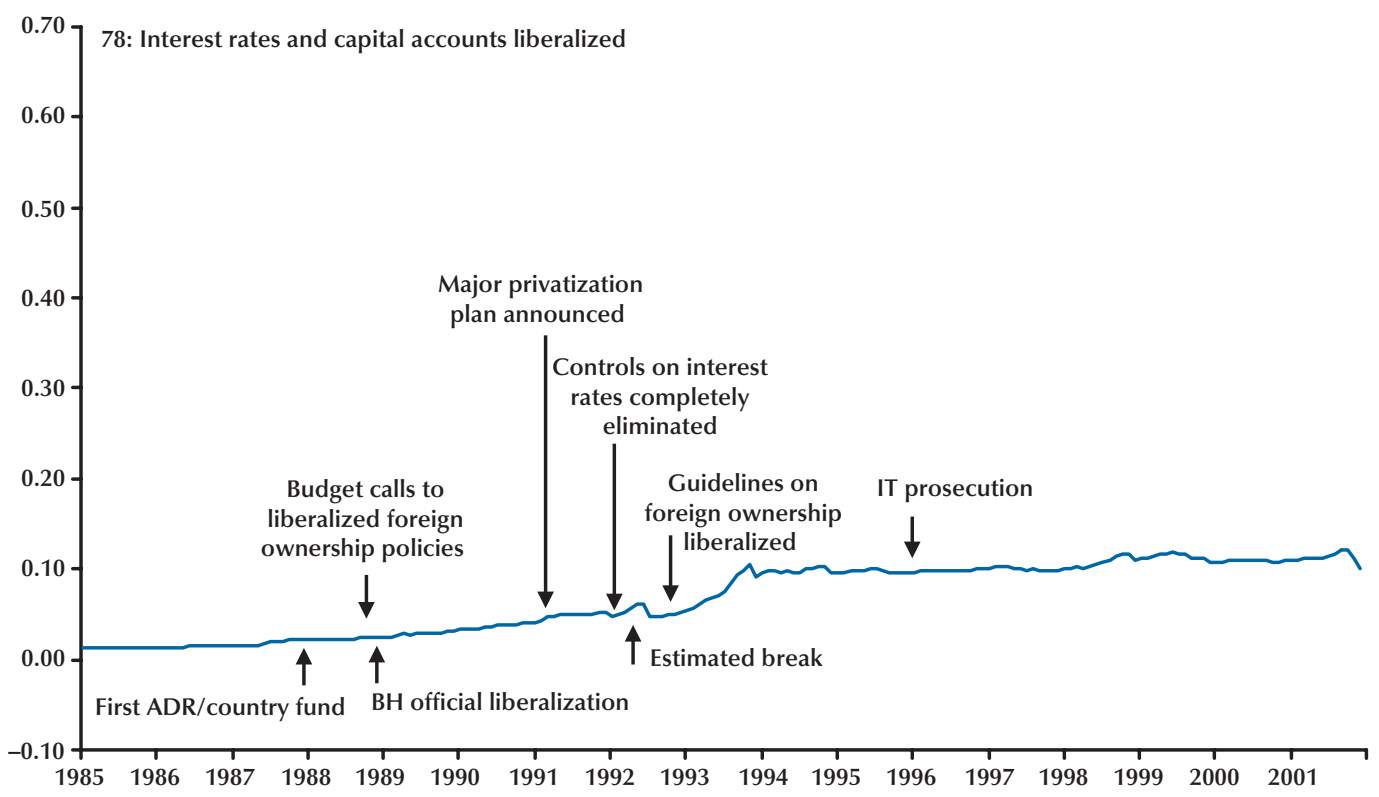

\section{U.S. Share of MSCI Market Capitalization in Mexico}

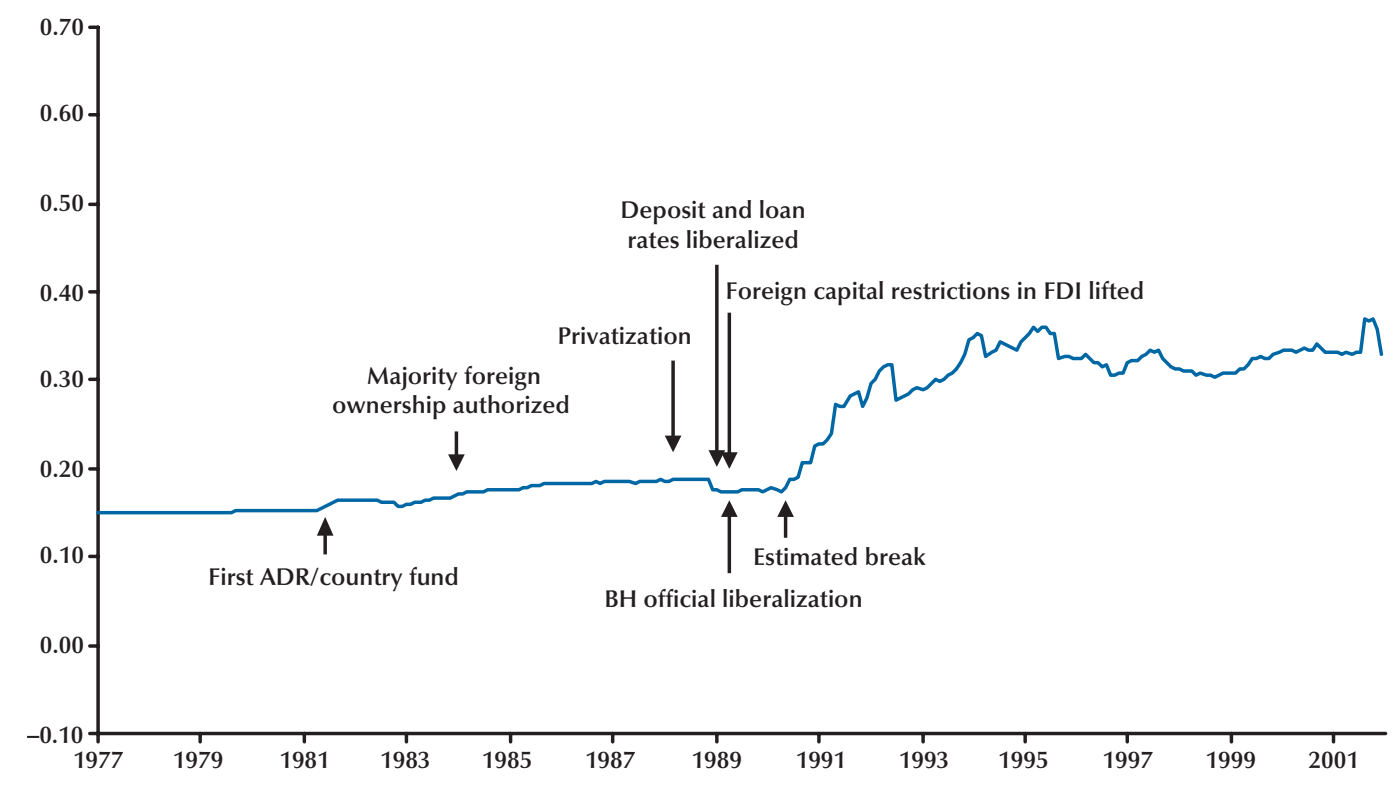




\section{Figure 3K}

\section{U.S. Share of MSCI Market Capitalization in Philippines}

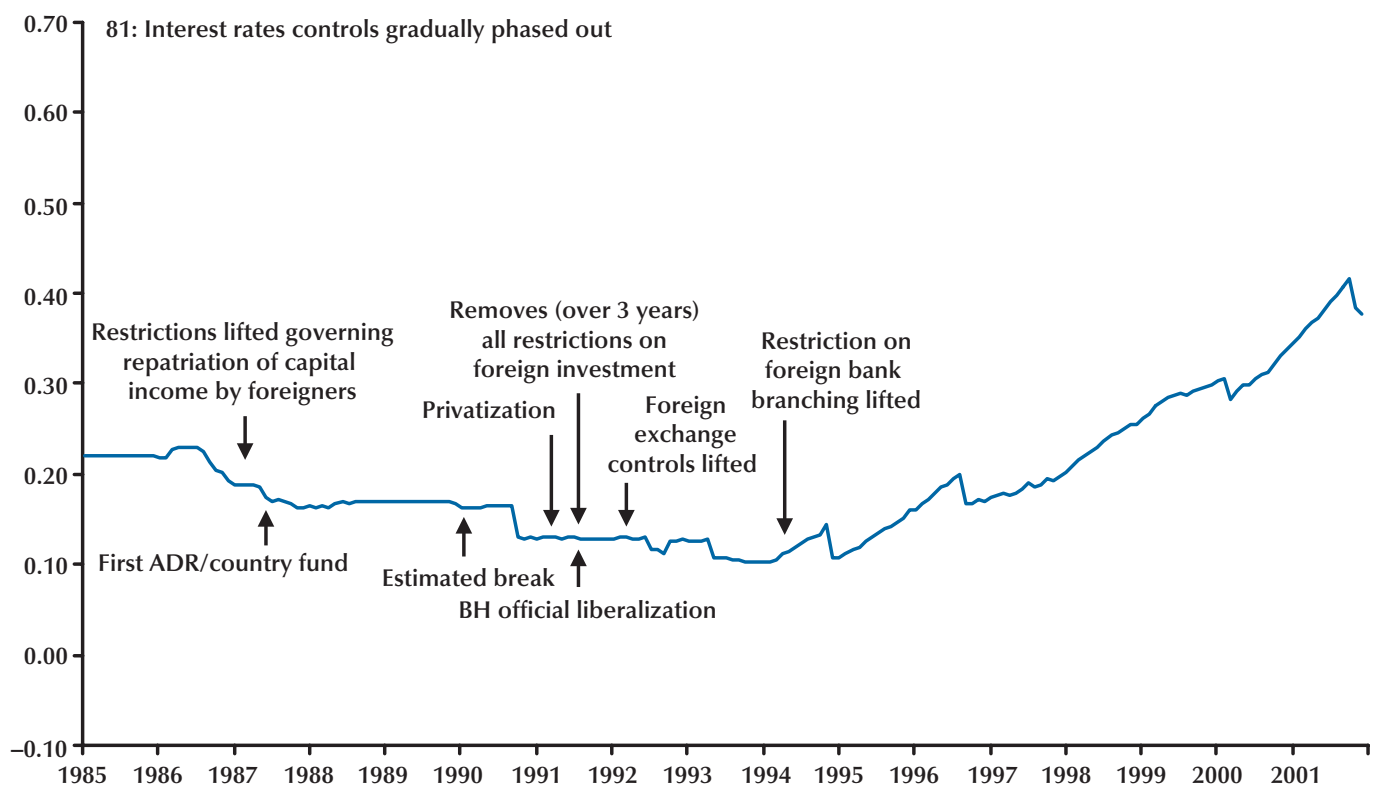

\section{U.S. Share of MSCI Market Capitalization in Portugal}

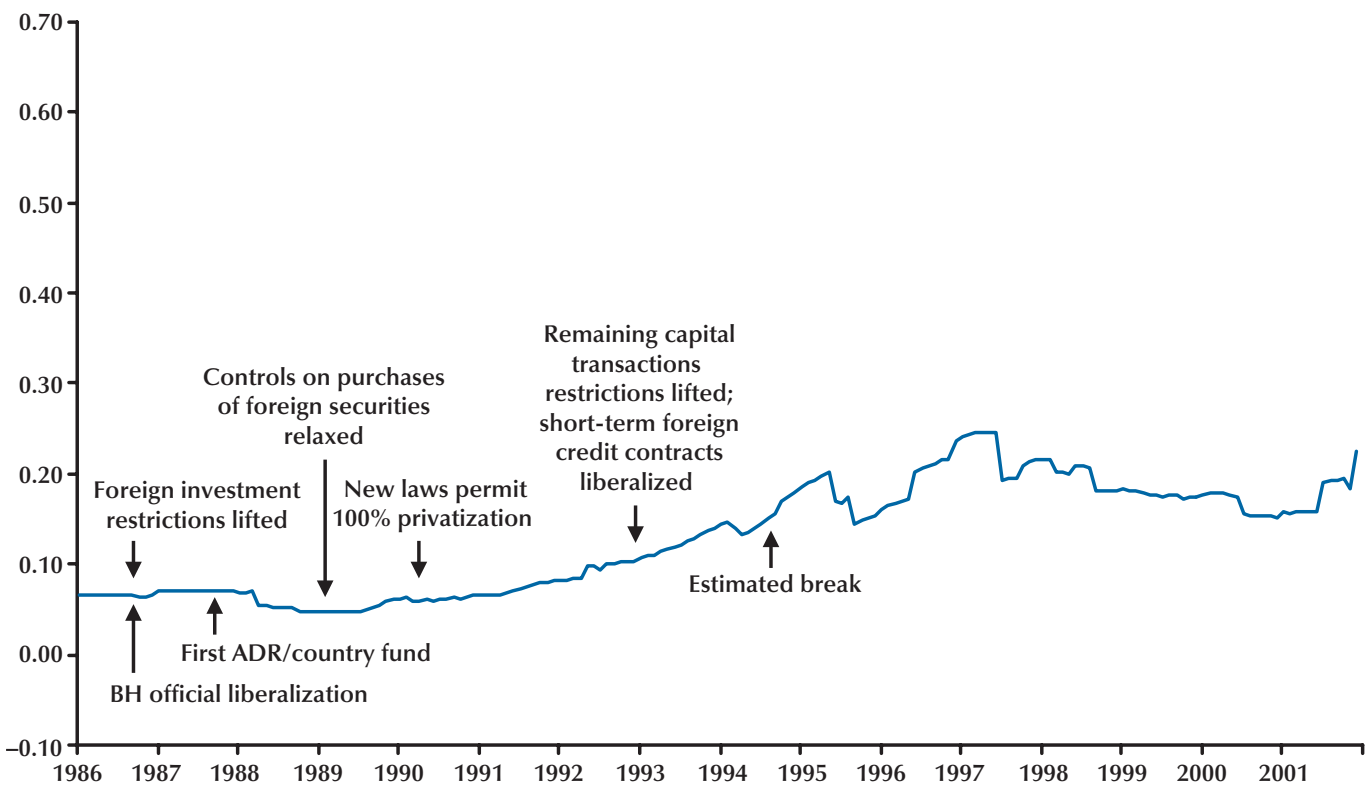




\section{Figure 3M}

\section{U.S. Share of MSCI Market Capitalization in Taiwan}

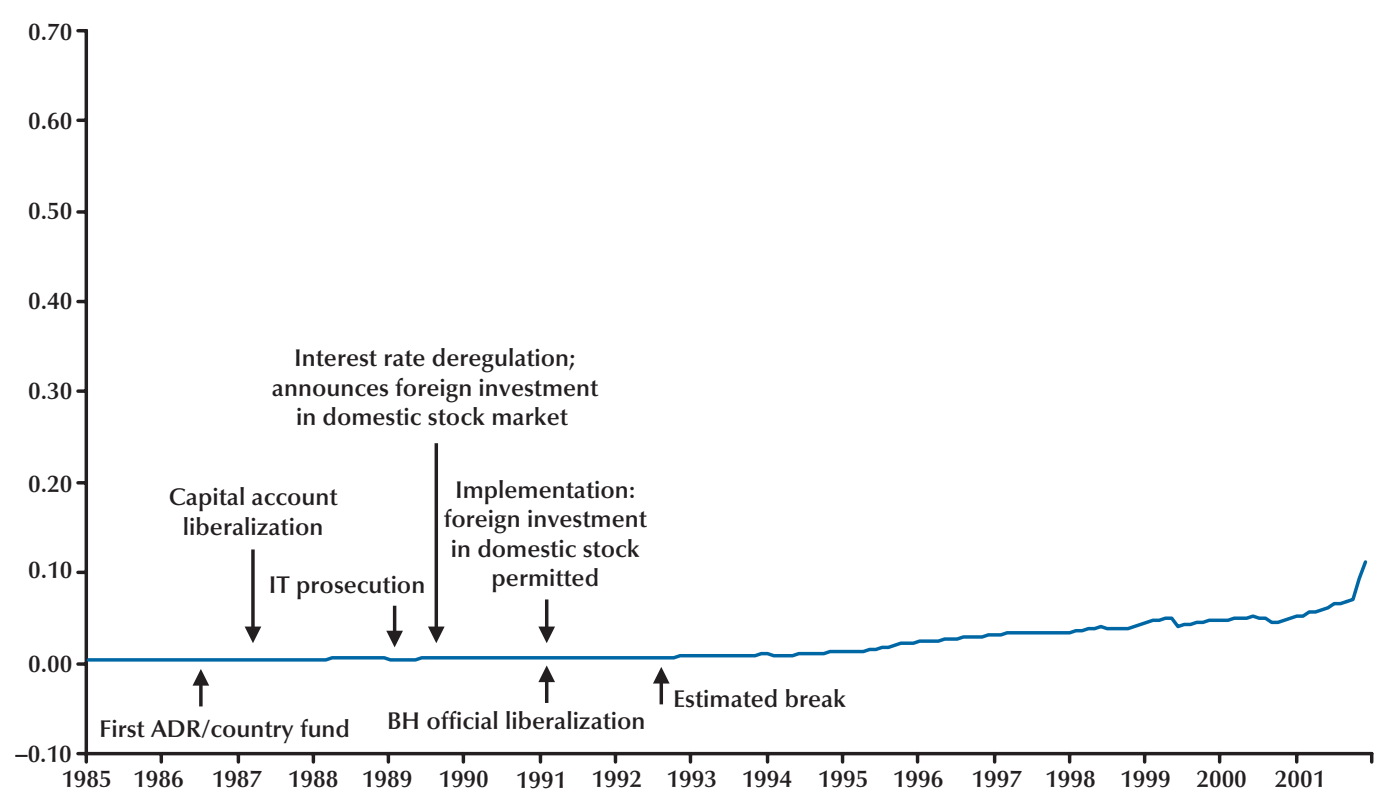

\section{U.S. Share of MSCI Market Capitalization in Thailand}

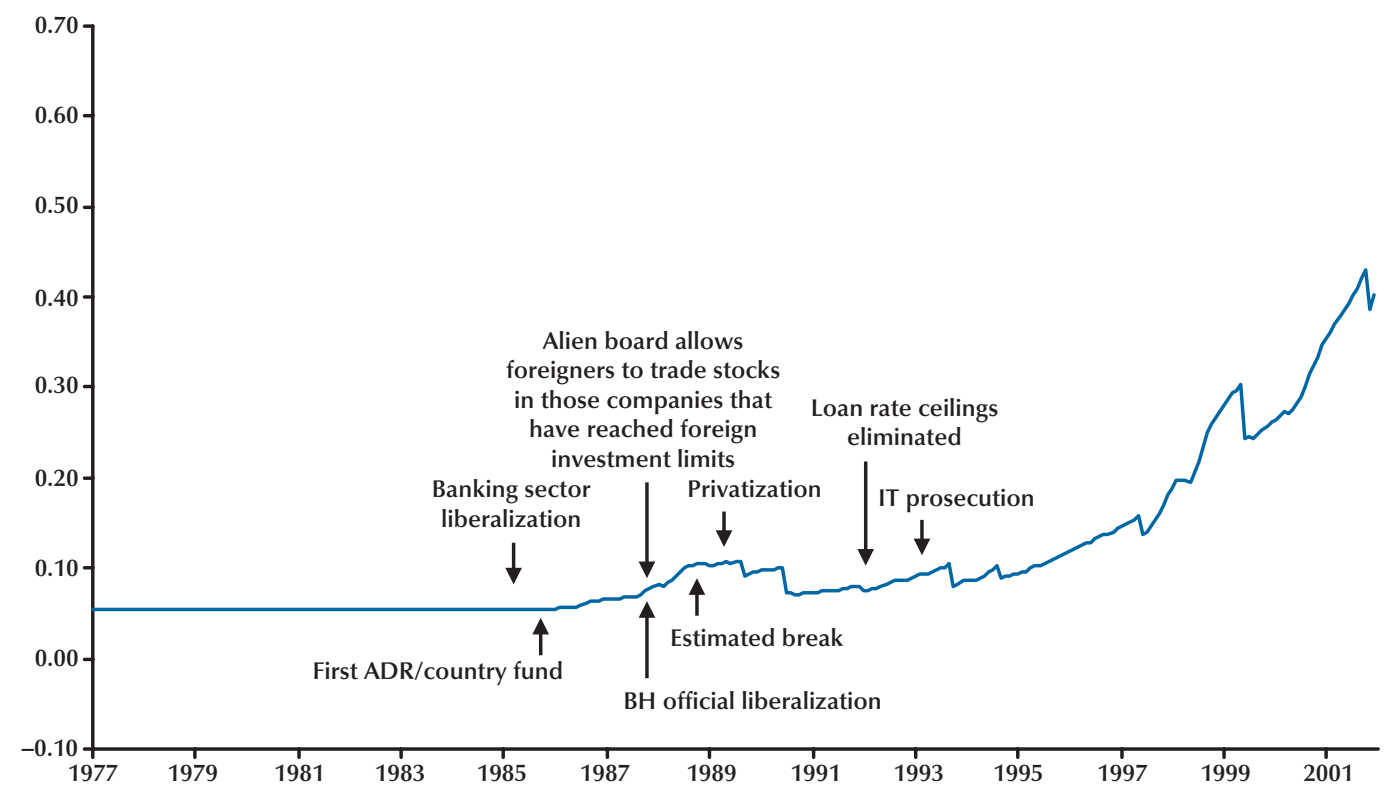




\section{U.S. Share of MSCI Market Capitalization in Turkey}

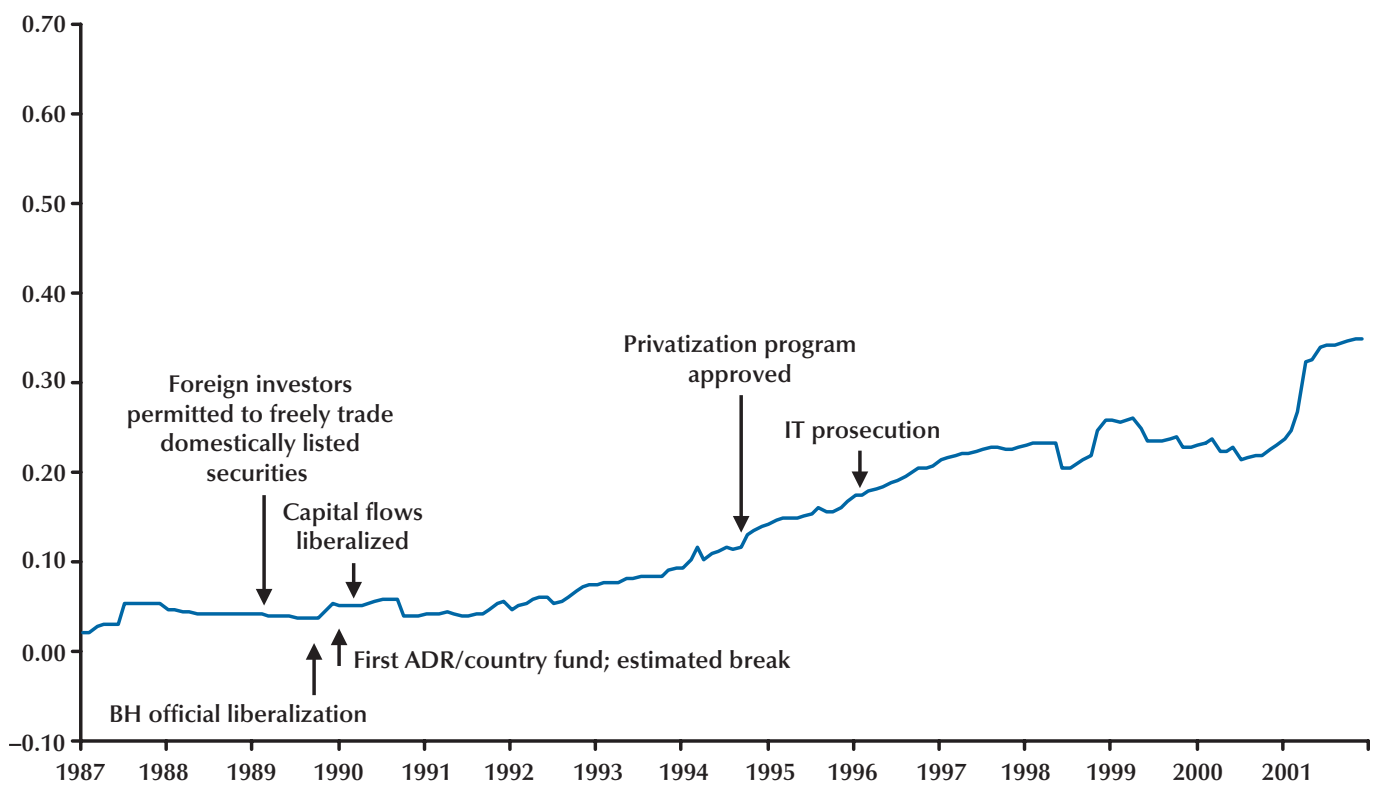

\section{U.S. Share of MSCI Market Capitalization in Venezuela}

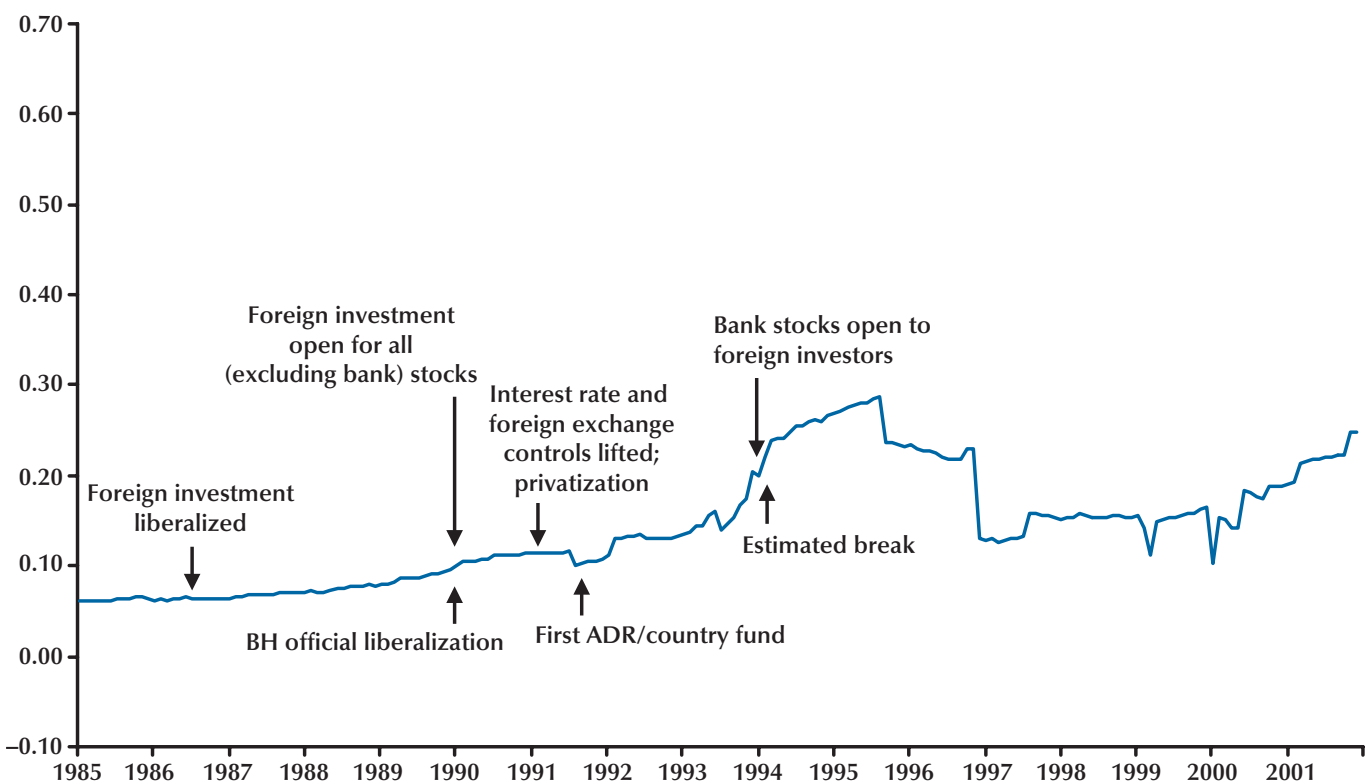




\section{Figure 4}

\section{Real GDP Growth Before and After Financial Liberalization}

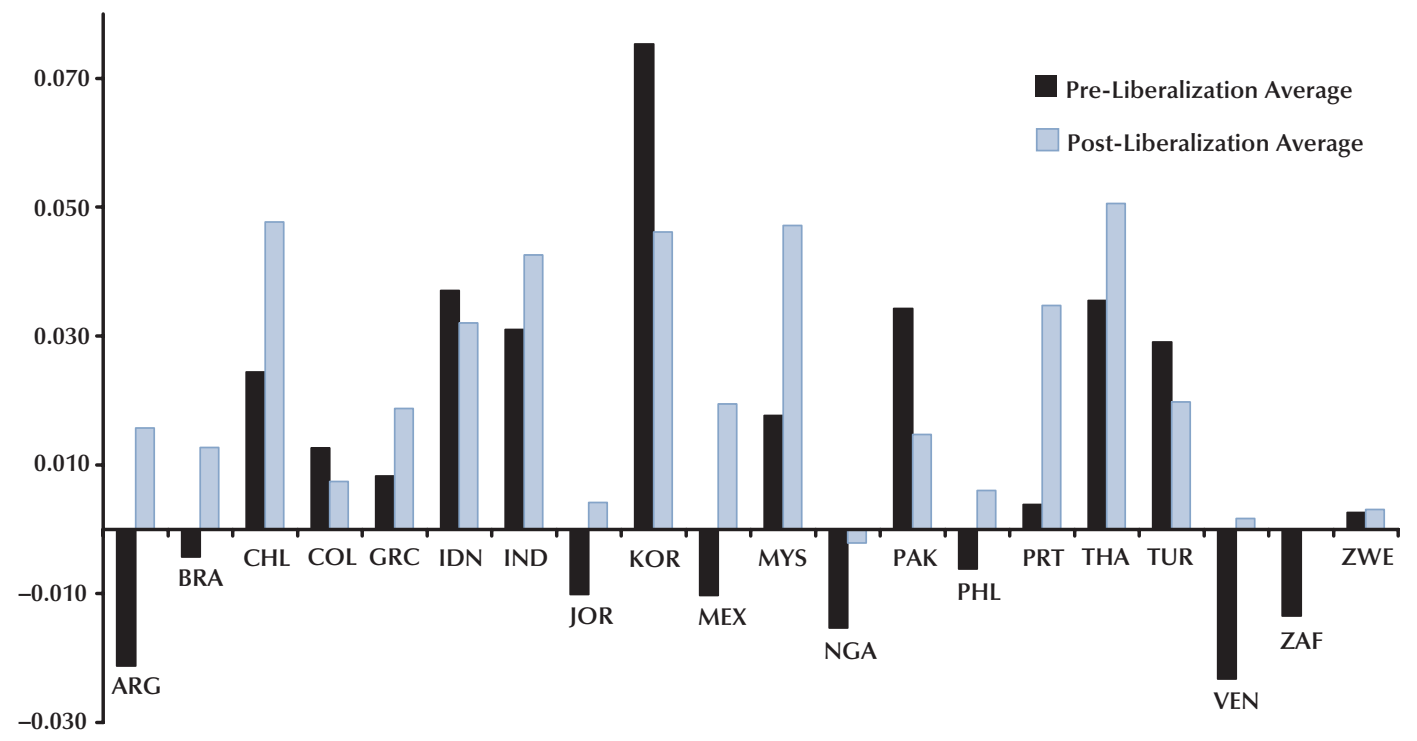

NOTE: For country abbreviations, see Table 1.

SOURCE: Liberalization dates: Bekaert and Harvey (2000).

over the 1980-97 period, Bekaert, Harvey, and Lundblad (2001) document that an "official equity market liberalization" leads to an increase in average annual per capita GDP of around 1 percent, control ling for other macroeconomic, demographic, and financial factors that have been shown to predict cross-sectional variation in economic growth. We explore GDP and investment growth across a similar set of countries here, updating our data set to include the highly influential South East Asian crises, for which several countries in that region actually contracted by more than 10 percent. For example, according to the World Bank, real per capita GDP growth in 1998 was -12.1 percent in Thailand, -15.7 percent in Indonesia, and -7.8 percent in Korea.

\section{Summary Statistics}

For the 30 emerging markets (excluding Taiwan due to World Bank data limitations) that we consider above, we collect annual data on real per capita GDP and investment extending from 1980 to 2000 from the World Bank Development Indicators CD-ROM $(<w w w . w o r l d b a n k . o r g>$ ). Figures 4 and 5 present evidence on annually observed rates of economic and investment growth, respectively, both before and after the $\mathrm{BH}$ official liberalization dates presented in Table 1. As can be seen from the graphs, the majority of these countries exhibit larger average economic growth after financial liberalization, even when the crisis years are included. With that in mind, the observed average difference across liberalization regimes is a remarkably robust feature of the data. Investment growth is similarly larger, on average, for most countries; however, Zimbabwe has a very large negative average investment rate after liberalization. This is due to an extremely large investment contraction in 2000. (GDP also contracts, but by a considerably smaller margin.) This drop in investment is likely due to the extensive political turbulence in that country at the end of our sample. ${ }^{4}$ Nevertheless, investment growth is, on average, higher for liberalized countries.

\section{Emerging Economies and Liberalization}

Following Bekaert, Harvey, and Lundblad (2001 and 2002), we exploit the following regression specification:

\footnotetext{
4 Zimbabwe faced its worst economic crisis since independence, with unemployment, interest rates, and inflation all soaring to record highs in 2000
} 


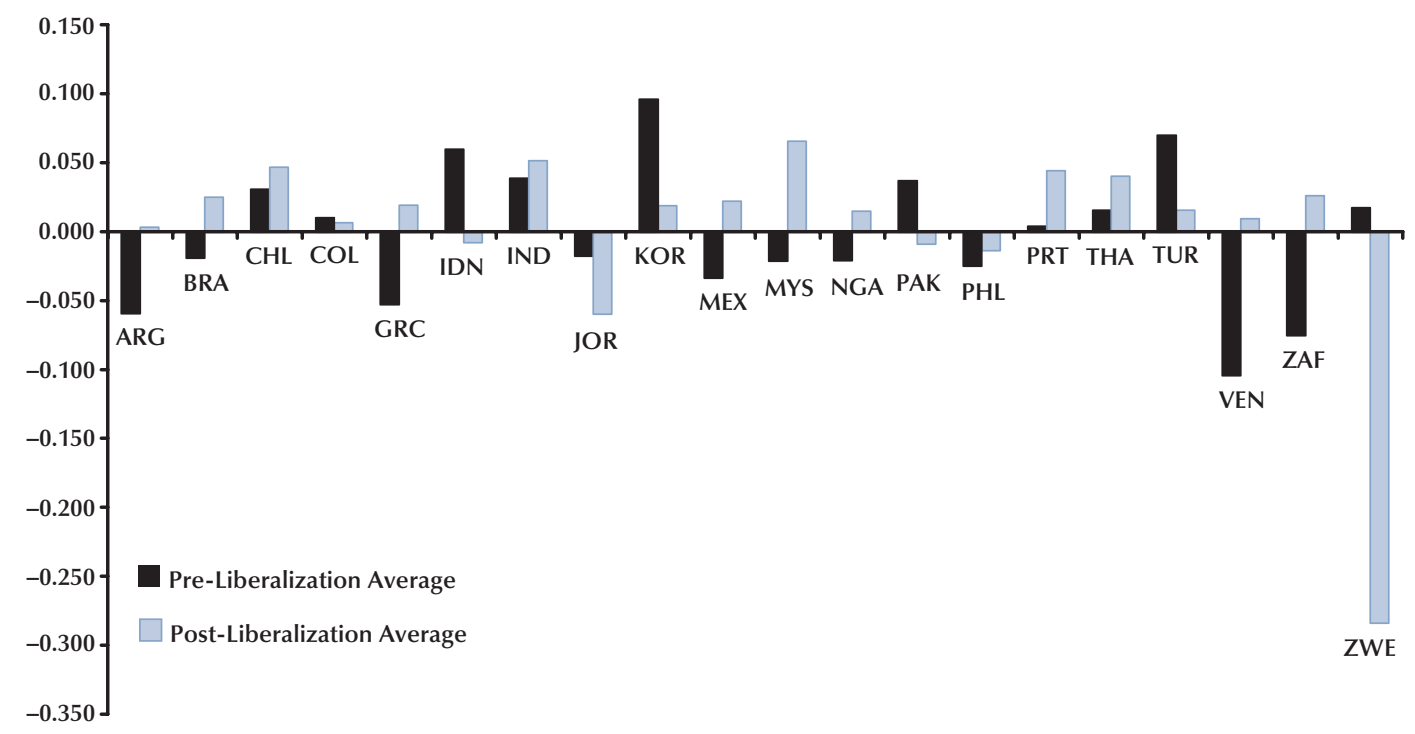

NOTE: For country abbreviations, see Table 1.

SOURCE: Liberalization dates: Bekaert and Harvey (2000).

(2)

$$
y_{i, t+1}=\beta_{i, 0}+\beta_{1} \cdot \mathbf{L i b}_{\mathbf{i}, \mathbf{t}}+\varepsilon_{i, t+1},
$$

where $y_{i, t}$ is the one-year growth rate in either real per capita GDP or investment and $\mathbf{L i b}_{\mathbf{i}, \mathbf{t}}$ denotes a liberalization indicator variable that takes a value of 1 when the equity market is officially liberalized and 0 otherwise. BH official liberalization dates are presented in Table 1 . We estimate the pooled time-series cross-sectional regression by GMM (see Hansen, 1982), correcting for groupwise heteroskedasticity and SUR effects. We also employ a simple fixed-effects estimator to directly soak up other country-specific factors that might affect economic and investment growth. To conserve space, we do not present the fixed effects.

In Table 4, we present estimates of the relation between real economic growth rates and the $\mathrm{BH}$ official equity market liberalization indicator. Consistent with the evidence on the pre- and postliberalization average growth rates presented in Figures 4 and 5, these estimates demonstrate a positive and statistically significant relation between the BH official equity market liberalization and both GDP and investment growth. Specifically, consistent with Bekaert, Harvey, and Lundblad (2001), the evidence implies that real GDP per capita growth rates increase by 0.84 percent (standard error 0.16 per- cent), on average, across the countries considered here following financial liberalization. Similarly, consistent with Henry (2000b), real investment growth increases by 2.2 percent (standard error 0.73 percent), on average. These differences suggest a significant economic affect associated with the introduction of foreign investors to the domestic equity market.

As emphasized above, the dating of an equity market liberalization is not a clear-cut empirical exercise. Hence, when exploring the economic affects associated with the official regulatory reform, an examination of the robustness of these effects to alternative dating schemes is required. For this reason, as in Bekaert, Harvey, and Lundblad (2002), we reestimate the regressions presented above, using two alternative sets of equity market liberalizations. The first set of dates is what they refer to as "first sign" dates-that is, the earliest of the three dates presented in Table 1: official liberalizations, first ADR announcement, and first country fund launch. The second line of Table 4 suggests that the liberalization coefficients are robust to using the "first sign" dates, as the estimated effects for both GDP and investment growth are virtually identical.

Second, given the limitation of the 0/1 liberaliza- 


\section{Table 4}

\section{Real Economy Effects of an Equity Market Liberalization Sample: 30 Countries}

\begin{tabular}{|c|c|c|c|c|}
\hline & \multicolumn{2}{|c|}{$\begin{array}{l}\text { Panel A: One-year GDP growth } \\
\text { fixed effects (not reported) }\end{array}$} & \multicolumn{2}{|c|}{$\begin{array}{l}\text { Panel B: One-year investment } \\
\text { fixed effects (not reported) }\end{array}$} \\
\hline & Estimate & Standard error & Estimate & Standard error \\
\hline Official liberalization & 0.0083 & 0.0013 & 0.0232 & 0.0057 \\
\hline First sign & 0.0082 & 0.0014 & 0.0264 & 0.0057 \\
\hline Investability & 0.0108 & 0.0022 & 0.0325 & 0.0111 \\
\hline
\end{tabular}

NOTE: The regression we perform includes observations on 30 countries from 1980 through 2000 . The dependent variable is either the one-year average growth rate of real per capita GDP (Panel A) or real per capita domestic investment (Panel B). We include in the regressions, but do not report, country-specific intercepts (fixed effects). We report the coefficient on the official liberalization variable that takes a value of 1 when the equity market is liberalized and 0 otherwise. The first sign liberalization indicator takes the value of 1 after the first of the following events: the official liberalization date, the introduction of an ADR, or the introduction of a country fund. The intensity measure is the ratio of IFC investables to global market capitalization from Edison and Warnock (2001). The weighting matrix we employ in our GMM estimation provides a correction for cross-sectional heteroskedasticity.

tion indicator employed above, we also reestimate the regressions above, employing the continuous investability measure from Edison and Warnock (2001). Recall, a ratio of 1 indicates that all of the domestic stocks are available to foreign investors. In Table 4, we call this the "investability" measure. The estimates reported in Table 4 can be interpreted as the liberalization effect for countries which are fully open. The effect is, not surprisingly, stronger than the "coarse" liberalization effect. For example, the GDP and investment growth effects of a full equity market liberalization are 1.1 percent and 3.3 percent, respectively, and both are highly significant. For a more elaborate analysis, including the growth effects for various horizons, the effect of control variables, and an exploration of the channels of growth, see Bekaert, Harvey, and Lundblad (2002).

\section{CONCLUSION}

The integration of emerging equity markets into world capital markets is best thought of as a structural change. Integration impacts the functioning of the equity market, the cost of capital, the diversification ability of local participants, the level of prices, the business focus of local companies, and foreign capital flows. The financial changes spill over into the real economy. It makes sense that a lower cost of capital is associated with increased investment and better prospects for GDP growth.

Our paper has focused on the different routes that a country can take to liberalize its equity market.
We explored the methods by which researchers can date the integration of world equity markets. The dating is a critical exercise. Only when dates are established can research begin to measure the impact of liberalizations. Given the considerable variation in liberalization initiatives, a closer analysis of the sequencing of liberalizations is an important focus of future research.

\section{REFERENCES}

Atje, Raymond and Jovanovic, Boyan. "Stock Markets and Development." European Economic Review, April 1993, 37(2-3), pp. 632-40.

Bai, Jushan; Lumsdaine, Robin and Stock, James H. "Testing for and Dating Common Breaks in Multivariate Time Series." Review of Economic Studies, July 1998, 65(3), pp. 395-432.

Bekaert, Geert. "Market Integration and Investment Barriers in Emerging Equity Markets." World Bank Economic Review, January 1995, 9(1), pp. 75-107. and Harvey, Campbell R. "Time-Varying World Market Integration.” Journal of Finance, June 1995, 50(2), pp. 403-44.

and "Foreign Speculators and Emerging Equity Markets." Journal of Finance, April 2000, 55(2), pp. 565-613. 
and Lumsdaine, Robin L. "Dating the Integration of World Equity Markets." Journal of Financial Economics, August 2002a, 65(2), pp. 203-247.

and _. "The Dynamics

of Emerging Market Flows.” Journal of International Money and Finance, June 2002b, 21(3), pp. 295-350.

and Lundblad, Christian.

"Emerging Equity Markets and Economic Development." Journal of Development Economics, December 2001, 66(2), pp. 465-504.

and "Does Financial

Liberalization Spur Growth?” Working paper, Duke University, 2002

Chuhan, Punam. "Are Institutional Investors an Important Source of Portfolio Investment in Emerging Markets?" Policy Research Working Paper No. WPS1243, World Bank, 1994.

Edison, Hali J. and Warnock, Francis E. "A Simple Measure of the Intensity of Capital Controls." Working Paper No. 01/180, International Monetary Fund, 2001.

Hansen, Lars P. "Large Sample Properties of Generalized Method of Moments Estimators.” Econometrica, July 1982, 50(4), pp. 1029-54.

Henry, Peter Blair. "Stock Market Liberalization, Economic Reform, and Emerging Market Equity Prices." Journal of Finance, April 2000a, 55(2), pp. 529-64.

"Do Stock Market Liberalizations Cause Investment Booms?" Journal of Financial Economics, October/November 2000b, 58(1-2), pp. 301-34.

Kim, E. Han and Singal, Vijay. "Stock Market Openings: Experience of Emerging Economies." Journal of Business, January 2000, 73(1), pp. 25-66.
King, Robert G. and Levine, Ross. "Finance, Entrepreneurship and Growth: Theory and Evidence." Journal of Monetary Economics, December 1993, 32(3), pp. 513-542.

Levine, Ross and Zervos, Sara. "Stock Markets, Banks, and Economic Growth.” American Economic Review, June 1998a, 88(3), pp. 537-58. and "Capital Control Liberalization and Stock Market Development." World Development, July 1998b, 26(7), pp. 1169-83.

Love, Inessa. "Financial Development and Financing Constraints: International Evidence from the Structural Investment Model." Unpublished manuscript, Columbia University, 2000.

Miller, Darius. "The Market Reaction to International Cross-Listings: Evidence from Depositary Receipts.” Journal of Financial Economics, 1999, 51(1), pp. 103-23.

Morgan Stanley Capital International. MSCI Enhanced Methodology, May 2001. < http://www.msci.com/ provisional/enhmeth_book.pdf $>$.

Standard and Poor's. The S\&P Emerging Market Indices: Methodology, Definitions, and Practices. February 2000. <www2.standardandpoors.com/spf/doc/index/ method.doc $>$.

Thomas, Charles and Warnock, Francis E. "International Equity and Bond Portfolios." Unpublished manuscript, Board of Governors of the Federal Reserve System, 2002.

Warnock, Francis E. and Cleaver, Chad. "Financial Centers and the Geography of Capital Flows." International Finance Discussion Paper No. 2002-722, Board of Governors of the Federal Reserve System, 2002. 